WORKING PAPER 3/2019

FINANCIAL FLOWS CENTRALITY: EMPIRICAL EVIDENCE USING BILATERAL CAPITAL FLOWS

Rogelio V. Mercado, Jr.

Shanty Noviantie

The South East Asian Central Banks (SEACEN) Research and Training Centre (80416-M)

Kuala Lumpur, Malaysia 
WORKING PAPER 3/2019

\section{FINANCIAL FLOWS CENTRALITY: EMPIRICAL EVIDENCE USING BILATERAL CAPITAL FLOWS}

Rogelio V. Mercado, Jr. *

Shanty Noviantie**

December 2019

* Senior Economist, The SEACEN Centre, rogelio.mercado@seacen.org.

** Senior Financial Sector Specialist, The SEACEN Centre, shanty@seacen.org.

The authors are grateful to the comments and suggestions of Hans Genberg, Maria Theresa Punzi, and Ole Rummel. The views expressed in this paper are those of the authors alone and do not reflect the official views of the South East Asian Central Banks (SEACEN) Research and Training Centre. 


\begin{abstract}
This paper uses a dataset on bilateral capital flows to construct a financial centrality measure for 64 advanced and emerging economies from 2000-16 to capture an economy's importance within the global financial flows network. The results highlight the varying significance of network systemic and idiosyncratic factors in explaining financial centrality across different types of investments and residency of investors. Most notably, the findings show that financial centres have deeper and more developed financial system, implying their importance in global financial intermediation.
\end{abstract}

Keywords: $\quad$ Financial Centrality, Financial Depth, Network Analysis

JEL Classification: D85, F21, F36, and G15

Disclaimer: This Working Paper should not be reported as representing the views of SEACEN or its member central banks/monetary authorities. The views expressed in this Working Paper are those of the author(s) and do not necessarily represent those of SEACEN or its member central banks/monetary authorities. 


\section{Table of Contents}

Page

Abstract iii

I. Introduction 1

II. Conceptual Framework 4

III. Bilateral Capital Flows and Financial Flows Centrality 6

A. Bilateral Capital Flows Data and Stylised Facts 6

B. Financial Flows Centrality and Stylised Facts 8

IV. Empirical Specification and Data Sources 11

V. Results and Analysis 13

A. Baseline Results and Extensions 13

B. Sensitivity Tests

VI. Concluding Remarks 16

References 18

List of Figures

Figure 1: Schematic Diagram of Reporting Bilateral Capital Flows 21

Figure 2: Aggregation of Multiple Reported Asset and Liability Flows 22

Figure 3: Centrality of Financial Flow Network 23

Figure 4: Eigenvector Centrality Index at Network Level 24

Figure 5: Multiplex Financial Flow Networks 25

\section{List of Tables}

Table 1: Bilateral Financial Account Flows Data 28

Table 2: Bilateral Capital Flows, $2016 \quad 29$

Table 3: Summary Statistics $\quad 30$

Table 4: Determinants of Centrality - Baseline Results 31

Table 5: Determinants of Centrality - Advanced Economies 32

Table 6: Determinants of Centrality - Emerging Economies 33

Table 7: Determinants of the Likelihood of Centrality - Top Quartile 34

Table 8: Determinants of the Likelihood of Centrality - Top Decile 35

Table 9: Determinants of Centrality - Global Factors 36

Table 10: Determinants of Centrality - Domestic Factors 37 


\title{
FINANCIAL FLOWS CENTRALITY: EMPIRICAL EVIDENCE USING BILATERAL CAPITAL FLOWS
}

\author{
By \\ Rogelio V. Mercado, Jr. \\ and \\ Shanty Noviantie
}

\section{Introduction}

The existing literature on financial network analysis focuses on financial links or ties between economies; whereas studies on cross-border transmissions highlight core-periphery dynamics. These concepts differ from financial centrality, which maps the importance and interconnectedness of economies within the global financial flows network. Economies that exhibit a high degree of financial centrality suggest their importance as sources or destinations of investments; as well as their vital role in global financial intermediation. As such, financial centres have greater impact on capital flows to and from other economies. However, most existing studies on the global financial network focus on the interconnectedness of economies within the international financial system. For instance, Hale (2012) considered the dynamic structure of the interconnectedness of the global banking network during expansions and contractions. Demirer et al. (2016) investigated the impact of systemic risks on the interconnectedness of global financial system using global bank equity and sovereign bond prices. Minoiu and Reyes (2013) focused on the pro-cyclicality of global banking network density before, during, and after crisis. These studies apply network analysis in understanding the topology of financial networks across different periods. In contrast, Ding et al. (2019) considered the inter-relationship and link between trade and financial holdings centrality.

However, no study has considered the determinants of financial centrality in the context of the global financial flows network. Understanding the drivers of an economy's importance has implications on financial stability, policy transmissions, and risk-spillovers analysis. Economies with a high degree of financial centrality play a greater role in the intermediation of global capital flows. In addition, financial centres include economies that are large net capital exporters or importers; and hence, play a crucial role in determining the volume of cross-border flows. Consequently, financial centres must maintain macroeconomic and financial stability as their financial linkages are greater than those in the exterior. More importantly, instability in these centres may cause impairment of global financial intermediation which will have a broader impact on the international financial system. But financial centres in the context of global financial flows networks are dynamic. An economy may be a centre for a few years, while another may consistently remain a centre. Such shifts in centrality positions cause network instability, leading to changes in network topology. Given the importance of financial centres in the global financial flows network, this paper asks: what 
are the significant drivers of financial centrality? Put differently, what factors covary with an economy's importance within the global financial flows network.

In understanding the determinants of financial centrality, this paper proposes two new ideas. First, we define financial centrality and how it can be measured. Financial centrality differs from the concept of economic cores and centres. For instance, Bordo and Flandreau (2003) defined core economies as those that have greater exchange rate flexibility, while peripheries are those that have trouble pegging but fear a floating exchange rate regime. Kaminsky and Reinhart (2003) define centres as large economies where systemic shocks may originate. Rey (2013 and 2016) defined the centre as the driver of global financial cycle which triggers cross-border capital flows and financial leverage across economies depending on its monetary policy and uncertainty. In this context, as opposed to a pre-defined centre, this paper considers the concept of financial centrality in terms of importance in cross-border financial investments and financial intermediation which may vary across economies and through time. In this paper, financial centrality refers to importance of economies within the global financial flows network. Based on this definition, importance pertains to how large and extensive financial ties between an economy and others in terms of being a borrower, lender, or financial intermediary; as well as the importance of its counterparties in the same network. This definition is consistent with Davis (1979) who defined network centrality as a node's or an economy's importance, control or influence within a network. Moreover, our definition is also consistent with Ding et al. (2019), although we consider importance to include an economy's role as borrower, lender and/or financial intermediary in the network. Our measure of financial centrality is based on the eigenvector centrality metric which combines the connections an economy has, weighted by the volume of transactions, and the importance of its counterparties in the global financial network.

Second, in considering the determinants of financial centrality, we include network systemic as well as idiosyncratic factors. Network systemic factors are those that affect the entire global financial flows network. These are time-varying factors common to all nodes or economies. In contrast, idiosyncratic factors are those that affect an individual node or economy within the global financial network. These factors can be either cyclical or structural. Cyclical factors are those affecting a given node or an economy at a given point in time which have a stronger time-varying component; whereas structural factors are those that influence a node or an economy for a longer period and capture peculiarities or uniqueness of a node or economy. ${ }^{1}$ These factors account for the static and dynamic evolution of the financial network topology.

To address the research question in this paper, we proceed as follows. First, we use bilateral capital flows data for 10 advanced reporting economies from Mercado (2018b), yielding 206 bilateral pairs for 2000-2016. The bilateral capital flows data include financial

\footnotetext{
${ }^{1}$ In the parlance of capital flows literature, these two factors are the global (push) and domestic (pull) factors.
} 
assets and liabilities across different functional categories of the Financial Account Balance; and they capture annual bilateral financial transactions as opposed to bilateral financial holdings. Second, using the bilateral capital flows data, we construct a financial centre measure based on the specific attribute of the financial network topology, namely the eigenvector centrality metric, yielding one financial centrality measure for each of the 64 advanced and emerging economies from 2000-16, which we then disaggregated by different types of investments and investor residency. The stylised facts show the changing financial centrality of economies across period. Nonetheless, there are economies such as France, Switzerland, and the United Kingdom which maintained their positions as financial centres before, during, and after the global financial crisis. Third, we regress our financial centrality measure on various global and domestic factors to assess the significance of network systemic and idiosyncratic factors.

The results indicate the importance of both network systemic and idiosyncratic factors in explaining cross-country and period variation in financial centrality. However, the findings show heterogenous patterns on the relevance of global and domestic factors on financial centrality depending on the residency and types of capital flows. For instance, although higher global risk aversion is significantly associated with lesser financial centrality for resident direct investments and other investments, it is highly associated with greater financial centrality for resident-based portfolio flows. Among factors considered, the results highlight the importance of financial depth as a key factor driving financial centrality across different types of financial transaction flows. These results are robust to various sensitivity tests.

These findings have empirical and policy implications. First, our empirical set-up, where we consider time-varying factors, implies that a network systemic shock can change the relative importance of economies within the global financial network. In contrast, static or period analyses do not capture time-varying systemic changes in the network as they focus only on idiosyncratic factors in analysing the topology of global financial networks. ${ }^{2}$ This implication warrants sound financial supervision and regulation as a defence against adverse systemic shocks, particularly for emerging economies (Chinazzi et al. 2013). Second, although other idiosyncratic factors such as domestic output growth and capital account openness are also significant, a developing and deepening domestic financial system is the most important factor driving an economy's importance in the global financial flows network. A more developed financial system fosters more efficient cross-border financial intermediation and hence, it raises the importance of an economy in the global financial network. The findings indicate the importance of network systemic factors as well as financial depth. Consequently, these require policy measures in safeguarding financial stability in response to global shocks while actively developing and deepening the domestic financial markets.

\footnotetext{
${ }^{2}$ Nonetheless, the impact of network systemic factors on financial centrality depends on idiosyncratic or domestic factors, most notably balance sheet effects of financial intermediaries (Battiston et al., 2012a and 2012b).
} 
Overall, the contributions of this paper are three-fold. First, this paper illustrates how bilateral capital flows data can be applied in financial network analysis. Unlike previous studies which used stock holdings data of specific asset type (Chinazzi et al., 2013; Craig and von Peter, 2014; Ding et al., 2019; Hale, 2012; and Minoiu and Reyes, 2013) or those that used asset price correlations (Demirer et al., 2016; Diebold and Yilmaz, 2014; and Li and Yang, 2017), bilateral capital flows data capture actual bilateral financial assets and liabilities transactions between two economies, where the values of financial flows are stripped of valuation effects due to price and exchange rate changes. Second, this study considers the determinants of financial centrality. By defining financial centrality in the context of an economy's importance within a global financial network relative to its trading or transacting counterparties, we are able to assess the significance of network systemic and idiosyncratic factors that drive the importance of an economy as borrower, lender, and/or financial intermediary within the international financial system. Consequently, we extend the literature on network centrality into the direction of identifying and assessing the determinants of network topology. Third, this paper also combines two strands of economic literature, namely that of financial network analysis and capital flows.

This paper proceeds as follows. We provide the conceptual framework on financial centrality and its determinants in Section II. Next, we discuss and provide stylised facts on the bilateral capital flows data and financial centrality measure in Section III. In Section IV, we provide the empirical specification and data sources, before presenting and discussing the baseline results and sensitivity tests in Section V. Finally, we conclude in Section VI.

\section{Conceptual Framework}

Empirical network analysis in economics and finance is often applied in the context of financial contagion mechanism, market interdependencies, and topology of financial network within an economy and across economies (Georg, 2013; Minoiu and Reyes, 2013; Hidalgo et al., 2015). In cross-border network analysis, empirical studies mostly focus on foreign investment and trade between some economies or the global banking network due to the lack of bilateral capital flows data at an aggregate level (Garlaschelli et al., 2007; Ding et al., 2019). Attempts have been made to predict the size of bilateral transactions at the country level by using gravity model, variance decomposition or correlation matrix (Battiston et al., 2010; Diebold and Yilmaz, 2014; Demirer et al., 2018). Such approaches, however, could not portray the actual to-and-from direction and transaction volume, which are important in characterizing the progression of a set of economies through sequence of states.

The to-and-from link or tie is the unit analysis in financial networks. A tie connects one node (representing an economy) to another allowing us to visualize and analyse the overall structure of cross-border financial flows including positions, interdependent properties, and tie distribution across nodes. Financial network structures are often characterised by measures of density, subgroup clustering, distance and centrality (Steketee et al., 2015). The latter has 
been extensively used to identify key players who can systemically influence the entire financial network.

Network centrality analysis portrays structural regularities of financial flows as a result of differential possession of finite resources at the nodes plus the structure of resources allocation at the ties. Consequently, our concept of financial centrality considers economies that are net borrowers or net lenders of capital as well as those that play an important role in global financial intermediation. Given that financial resources in the system are finite, ties could be asymmetrically reciprocal and time-varying in intensity (Borgatti et al., 2009). ${ }^{3}$ At network level, centrality metric measures variation in the economies' centrality degree or score within a financial network (Marsden, 2015). As such, our centrality measure conceptually differs from core-periphery model, as discussed in Leij et al. (2016). In general, core-periphery models assume all nodes in the core are completely connected to some periphery nodes and periphery nodes are not connected to other periphery nodes. In contrast, our centrality metric accounts for the importance of ties between two economies themselves and as part of the financial network in which both economies are embedded. It reveals not only the most influential or important economies such as the financial centres, but also possible ties between less important countries.

But in assessing the significance of covariates which accounts for cross-country variation of the financial centre metric within the global financial flows network, we also consider the determinants of capital flows which tie individual economies with each other. Specifically, we focus on global and domestic factors. The mechanics on how each can influence our financial centrality measure are as follows.

Consider three economies in the global financial flows network, $A, B$, and $C$ which are all non-financial centres within the network at time t. If economy $A$ experiences a positive demand shock at time $t+1$, then output, consumer prices, asset prices, and the interest rate will increase. This will encourage more cross-border capital inflows and outflows as the economy increases its role as lender or borrower (Giordani et al., 2017; Li et al., 2018; and Mercado and Park, 2011). Likewise, if economy A experiences greater financial depth, capital account liberalisation, and improvement in governance, then it improves its role as an international financial intermediary and hence it will register greater volume of capital flows (Alfaro et al, 2008; Byrne and Fiess, 2016; Ghosh et al., 2014; and Mercado and Park, 2011). Both idiosyncratic cyclical and structural changes enable economy A to play a more important role in the global financial network. Consequently, economy A becomes a financial centre; whereas economy $\mathrm{B}$ and $\mathrm{C}$ remain non-financial centres in the absence of domestic cyclical or structural changes.

\footnotetext{
${ }^{3}$ It is important to note that multiple types of relationships might exist between the same set of economies. If each type of relationship is represented as a single financial network, losing some financial centres in a specific network might have less global systemic consequences than the loss of one or two financial centres in multiple networks (Holland and Leinhardt, 1979; Wellman, 1983). Thus, network centrality analysis should be conducted at the node level and network level in multiplex networks.
} 
The growing importance of economy $\mathrm{A}$ at time $\mathrm{t}+1$ brought about by cyclical or structural changes may occur in the presence of network systemic factors which vary through time but are constant across all economies within the network. Suppose a systemic risk or global cyclical change occurs at time $t+2$, this may enhance or diminish economy A's importance depending on its domestic factors and exposures or linkages to other economies in the network. In other words, time-varying common factors may amplify structural and cyclical factors of all economies in the network. These global factors, which are systemic within the global financial flows network, may include global growth, global interest rate, global risk appetite, global liquidity, and global commodity prices. These factors are also those that drive cross-border capital flows. ${ }^{4}$ The extent that these systemic factors originate from the key financial centres such as the United States, Euro Area, and Japan, will determine the evolution of the topology of global financial flows network as well as the severity of crisis (Hale, 2012; and Minoiu and Reyes, 2013).

In both contexts, financial centrality depends on both global and domestic factors, which, likewise, drive cross-border capital flows. However, their impact on financial centrality within the network may depend on the type of asset or investment considered. There may be heterogenous effects across types of investment whereby some economies lend, borrow or intermediate using high or low asset returns and risks; or using varying debt and equity composition. Moreover, different types of investments may respond differently to changes in global and domestic factors depending on whether they are resident and non-resident driven flows (Calderón and Kubota, 2013). Consequently, there are heterogenous impacts of network systemic and idiosyncratic factors across types of investments and investors.

\section{Bilateral Capital Flows and Financial Flows Centrality}

\section{A. Bilateral Capital Flows Data and Stylised Facts}

To examine the determinants of financial centrality, this paper uses the bilateral capital flows dataset of Mercado (2018b). The main advantage of using bilateral capital flows data is that it offers greater understanding of financial network centrality as the underlying bilateral financial flows data is an aggregated total of all types of financial investment transactions including greenfield; mergers and acquisitions; portfolio securities; equities; loans; currency and deposits; trade credits and advances; and other types of payables and investments. In contrast, previous studies on geographic financial networks considered only one type of investments or specific sectoral flows. For instance, Ding et al. (2019) used the IMF's

\footnotetext{
${ }^{4}$ More recent papers on the determinants of the size of capital inflows show that higher global growth is significantly correlated with higher inflows to emerging economies (Li et al., 2018), while higher global or U.S. interest rate is strongly associated with lower capital inflows to emerging economies (Byrne and Fiess, 2016; Giordani et al., 2017; Ghosh et al., 2014; Koepke, 2018; Li et al., 2018; and Mercado 2018c). Higher commodity prices tend to increase capital inflows to emerging and developing economies (Byrne and Fiess, 2016; Mercado, 2018c; and Reinhart and Reinhart, 2009). Greater global risk aversion leads to lower or reversals of cross-border inflows, more so during periods of financial stress (Ahmed and Zlate, 2014; Fratzscher, 2012; Ghosh et al., 2014; and Giordani et al., 2017).
} 
Coordinated Portfolio Investment Survey to understand network centrality. Their data refer to stock holdings of portfolio equity and debt securities. Minoiu and Reyes (2013) used banking sector flows from the BIS locational banking statistics which includes loans, deposits, debt securities, and other bank assets but is limited to specific sectors. Hence, bilateral financial account flows data are more useful in understanding geographic financial network centrality. More importantly, the data pertain to the financial transactions between two economies, which represent actual financial flows between two nodes, as opposed to proxy measures of interconnectedness such as asset price correlations.

Mercado's (2018b) bilateral capital flows data are taken from Balance of Payments Statistics of 10 reporting central banks or statistics agencies, including Austria (Österreichische Nationalbank), Canada (Statistics Canada), Denmark (Danmarks Nationalbank), Germany (Deutsche Bundesbank), Japan (Bank of Japan), Korea (Bank of Korea), Netherlands (De Nederlandsche Bank), New Zealand (Stats NZ), Spain (Banco de España) and the United States (Bureau of Economic Analysis). ${ }^{5}$ Values are mostly presented in local currency units. To standardize across countries, values are converted to US dollar using the average foreign exchange rate taken from the International Financial Statistics of the IMF. The data cover annual values from 2000 to 2016. For some countries, quarterly or monthly data in USD millions are added annually. Confidential and unavailable data are treated as missing values; whereas zeros are included as they are. Reported values follow the Balance of Payments Manual 6 (BPM6), but in cases where values are based on Balance of Payments Manual 5, e.g. Japan for 2000-2013, bilateral assets flows are multiplied by -1 in lieu of BPM6 convention of having a positive sign to indicate an increase in assets. In total, our data set covers 206 bilateral pairs, as reported in Table 1.

The various types of bilateral capital asset flows include direct investment assets (FDIA), foreign direct investment liabilities (FDIL), portfolio assets (PORTA), portfolio liabilities (PORTL), other investment assets (OIA), and other investment liabilities (OIL). ${ }^{6}$ If bilateral total assets and liabilities are given, they are used in the data set. If not, total assets are computed as the sum of direct, portfolio, financial derivative assets (DERA), other investment and official reserve assets (RESA) whenever data are available. Total liabilities include direct, portfolio, financial derivatives and other investment liabilities. Following the naming convention in the capital flows literature, bilateral asset transactions refer to gross capital outflows, which pertain to domestic resident's financial acquisitions of foreign assets, while bilateral liabilities transactions refer to gross capital inflows.

\footnotetext{
5 Given the limited number of reporting economies, the dataset does not capture bilateral ties between two unreported economies. However, the sample is representative of the global financial flows given the inclusion of the United States, Japan, and Germany. On the average, the sample accounts for around 25 percent of world total bilateral holdings of direct and portfolio investments and bank claims.

${ }^{6}$ Some reporting economies also report the bilateral breakdown of their financial derivatives and reserve assets. However, the focus of our analysis is more to the three main components of capital flows. For Austria, foreign direct investment data mostly include direct investments of Special Purpose Entities (SPEs) and the real estate sector. However, for some economies, reported foreign direct investment assets and liabilities exclude these items.
} 
However, bilateral financial account assets and liabilities data are not a mirror image of each other as resident financial transactions with non-resident counterparties are not equal to non-resident financial transactions with resident counterparties due to differences in transactions and reporting standards. Figure 1 illustrates a schematic diagram showing the complexities of using bilateral capital flows data. It shows that some transactions are recorded based on the country of the ultimate owner, issuer and/or beneficiary. But most bilateral transactions are reported based on the location of the transacting counterparty such as those using financial intermediaries and/or custodians, which is in line with the residency principle of the BPM6. In the latter case, the country location of the ultimate owner, issuer, or beneficiary may or may not be known. For example, if a company in the reporting country A acquires a company in country $\mathrm{C}$ through an intermediary in country $\mathrm{B}$, bilateral transactions will be recorded between the reporting country $A$ and country $B$, even if the actual ownership is in country C. In practice, most countries report bilateral transactions based on the country location of the counterparty involved in that transaction. Table 1 summarizes the bilateral capital flows data and indicates whether each functional category of the Financial Account refers to the country location of the transacting counterparty $(\mathrm{TC})$ or the country location of the ultimate owner, issuer or beneficiary (UOIB).

To preview the data set, Table 2 presents the values of bilateral financial asset and liabilities flows of selected reporting to partner economies in 2016. The striking pattern we see is that there is a huge variation of reporting country's asset transactions with its partner economies. For instance, Japanese investors sold off assets in Germany but acquired more asset transactions with the United States in the same year. But Japan's reversal of asset flows to Germany was primarily directed to portfolio and financial derivative assets. In contrast, Germany reports an increase in liabilities from Japan due to direct and portfolio investments. These show that bilateral financial account data between two economies are not the mirror image of each other due to differences in transactions and reporting systems.

\section{B. Financial Flows Centrality and Stylised Facts}

The time-varying centrality can be captured in many ways. However, only the weighted degree and eigenvector centrality account for the size and intermediation of bilateral financial flows (lacobucci et al., 2017). Between these two metrics, we use the eigenvector centrality as our measure of financial centrality, although weighted degree centrality is used in our sensitivity test. The advantage of the eigenvector centrality is that it ranks the importance of nodes by combining the connections a node has weighted by the value of links (i.e. weighted degree centrality) and the weighted degree of nodes that it is connected to. Consequently, the eigenvector centrality considers the weighted degree of its counterparties, whereas the weighted degree centrality does not. As such, economies with more links will score higher under the weighted degree centrality, while economies with strong links with other important economies will score higher in the eigenvector centrality metric (Hansen et al., 2011). 
To derive our centrality measure, we proceed as follows. Let $\mathrm{n}$ denote the number of economies in the global financial network; and $\mathrm{W}=\left(\mathrm{w}_{-}(\mathrm{i}, \mathrm{j})\right)$ be the weighted-adjacency matrix of a directed graph $G=(V, E)$, where $V$ is a set of nodes and $E$ is a set of links composed of ordered node pairs. If economy $i$ is connected to economy $j, w_{-}(i, j)$ is greater than zero. The eigenvector centrality of economy $i$ at time $t$ is given by:

$$
x_{i, t}=\frac{1}{\lambda_{t}} \sum_{j \in M(i)}^{n} x_{j, t}=\frac{1}{\lambda_{t}} \sum_{i \in G}^{n} w_{i j, t} x_{j, t}
$$

where $\lambda \neq 0$ is a constant, $M(i)$ is a set of counterparties of $i$, and $x \_t$ is centrality vector of the adjacency matrix $W_{-} t$ associated with eigenvalue $\lambda_{-} t$. By way of the Perron-Frobenius theorem, we select the largest eigenvalue in absolute value of matrix $W$ _t as value of $\lambda \_t$. This will guarantee that eigenvector solution $\mathrm{x}$ is unique and positive when matrix $\mathrm{W}$ is irreducible, or the graph is strongly connected. We solve the eigenvector centrality by using the power method. ${ }^{7}$ The weighted degree of economy $i$ at time $t$ is given by:

$$
d_{i, t}=\sum_{j} w_{j i, t}+\sum_{j} w_{i j, t}
$$

The first term on the right-hand side of Equation (2) computes in-degree of economy $\mathrm{i}$ whilst the second term is out-degree centrality of economy i (Barrat et al., 2004; Newman, 2004). The eigenvector and weighted degree centrality indices are computed at the node and network level for financial asset and liability flows of three main components of capital flows. ${ }^{8}$ It is important to note that ties or connections for a given financial network exist when financial assets and/or liabilities flow among a set of nodes. Three consequences of this are: (1) data must be in matrices and each element of matrices represents a tie or connection between two economies; (2) either two ties with opposite directions or one tie exists between two nodes; and (3) we take the absolute value of reversal investments as we are more interested in capturing the size of bilateral transactions.

Given that bilateral financial account data are not a mirror image between reporting economies, three or four ties representing bilateral financial transactions might appear between two reporting countries. Figure 2 illustrates Japan as a reporting economy. It invests in U.S. assets, represented by a cyan arrow from node JPN to node USA. Consequently, U.S., which is also a reporting economy has financial liability from Japan represented by a pink arrow from node USA to node JPN. At the same time, U.S. bilateral capital flow report

\footnotetext{
7 Let $x_{0}$ denote an arbitrary vector and $v(x)$ is signed component of the first maxima component of vector $x$. For $j \geq 1, x_{j}=x_{j-1} W$ and $x_{j}$ is normalized as $x_{j}=x_{j} / v\left(x_{j}\right)$. We repeat this iteration until $x_{j}$ converges to the dominant eigenvector of $W$ whilst $v(x)$ converges to the dominant eigenvalue (Watkins, 2010).

8 The network level index indicates whether there are some highly centralized nodes. Let $\ddot{x}=\max \left\{x_{1}, \cdots, x_{n}\right\}$ and network level of a centrality measure is defined as a $X=\frac{\sum_{i}\left(\ddot{x}-x_{i}\right)}{\max \sum_{i}\left(\ddot{x}-x_{i}\right)}$, where $0 \leq X \leq 1$. Zero $X$ means that all nodes have equal degree of centrality. Then, network with unity $X$ has only one node at the maxima and the rest of the nodes are at the minima (Newman, 2004).
} 
shows larger investment in Japanese assets represented by a denser blue arrow from node USA to node JPN; and smaller financial liability to Japan represented by a thinner red arrow from node JPN to node USA. In terms of gross capital flows, U.S. reported higher gross flows data than Japan's reported gross flows. In this study, we use data aggregated by country reporting the highest bilateral gross capital flows. In this case, we select U.S. data on asset and liability flow to Japan. Figure 2 also shows bi-directional links formed to another nonreporting economy, say Brazil, as both USA and Japan report bilateral financial asset and liability flows to Brazil, which is represented by node BRA in Figure 2.

To illustrate the dynamics of the eigenvector centrality overtime, we compare the eigenvector centrality metrices at network and node level across asset and liability flow networks. Eigenvector centrality at the node level indicates financial centres within that specific network. For instance, the U.S. invests in Germany, United Kingdom, Brazil and Japan while borrowing from Japan and Brazil. Brazil, concurrently, borrows from more economies then USA. It follows that the eigenvector centrality score for USA is above the 75th percentile of asset flow - centrality metric but below the 75th percentile of liability flow - centrality metric (Figure 3). Simply put, USA is a financial centre in the asset flow network, but it is Brazil being the financial centre in liability flow network. Figure 4 depicts eigenvector centrality metrices at network level for each type of investments. The centrality metrices measure the variation of the eigenvector centrality scores across nodes. The higher the value of the metrices, the more centred financial flows are in a number of economies. High variation of scores is observed in the direct investment network, implying that the network is more centred than other financial flow networks. In most cases, the eigenvector centrality scores reached their peak in 2008. This means a high number of financial centres shifted to the non-centre position during the global financial crisis (GFC) of 2008. It is interesting to note that a high number of new financial centres emerge in the asset and liability flow network two years before and four years after crisis. This conforms with the notion of pro-cyclicality of capital flows, consistent with Hale (2012) and Minoiu and Reyes (2013).

A shift in key financial centres before and after the crisis is indicated by changes in node colour, as depicted in Figures 5a to 5f. Advanced economy ( $A E$ ) financial centres are indicated by blue nodes; while emerging economy (EME) financial centres are represented by orange nodes. ${ }^{9}$ Yellow and turquoise nodes represent other EMEs and other AEs, respectively. The link density represents transaction volume and its colour indicates investment types: direct investment (grey links), portfolio (pink links) and other investment (light blue links). Across time, France, Switzerland, and the United Kingdom have been the major financial centres in the networks of asset and liability flows. This implies that the three economies play a pivotal role in the intermediation of financial flows and they may have global systemic impacts. Within the asset flow network, Luxembourg, Singapore, Belgium, China and Brazil were also major financial centres (Figure 5.a, 5.b and 5.e). Advanced economies such

\footnotetext{
${ }^{9}$ We define financial centres as economies with centrality score above the $75^{\text {th }}$ percentile of our financial centrality metric.
} 
as USA and Korea shifted to become non-centre economies during and after GFC. Interestingly, Cayman Island and South Africa became highly important during the crisis (Figure 5.c). For the liability flow network, key financial centres changed more rapidly but USA and Italy remained as major financial centres before and after the GFC. Chinese Taipei, India, and Hungary emerged as new financial centres during and after the crisis. These stylised facts illustrate the dynamic position of financial centres and the pro-cyclical nature of global financial flows network.

\section{Empirical Specification and Data Sources}

To assess the determinants of financial network centrality, we regress our computed financial centrality measure across various types of capital flows discussed in Section III.B on global and domestic factors. This approach follows the capital flows literature which considers the time-varying significance of both factors on different aspects of capital flows, including magnitude of different kinds, volatilities, and occurrence of extreme episodes. Specifically, we estimate the baseline results as:

$$
C F_{i, t}=\alpha_{i}+g_{t} \beta+d_{i, t-1} \gamma+\varepsilon_{i, t}
$$

where $C F_{i j, t}$ refers to the financial centrality measure of economy $i$ at year $t$ from 2000 to 2016 . The data pertains to the percentile value of our eigenvector financial centrality metric. $g_{t}$ is a row vector of global factors which are common across economies but vary per year. $d_{i, t}$ is a row vector of domestic factors which vary through time and for each economy. $\varepsilon_{i, t}$ pertains to robust standard errors. We estimate Equation (3) not only for net and total gross flows, but also direct, portfolio, and other investment outflows and inflows, to capture heterogeneous impacts of systemic and idiosyncratic factors.

As our underlying data for our centrality measure are bilateral capital flows, we include global factors in their contemporaneous values as capital flows instantaneously respond to current global factors (Ghosh et al., 2014; Li et al., 2018; and Mercado 2018a and 2018c).10 In contrast, domestic factors are included in their lagged value to minimise potential endogeneity concerns (Forbes and Warnock, 2012; and Ghosh et al., 2014). Equation (3) is estimated as pooled ordinary least squares. We do not add country and year effects so as not to diminish the significance of global and domestic factors with the inclusion of country and year dummy variables, like Forbes and Warnock (2012); Ghosh et al. (2014); and Mercado (2018a). Nonetheless, we run sensitivity tests by replacing domestic factors with country dummy variables and replacing global factors with year dummy variables to check whether the identified significant factors hold when either one is replaced by dummies.

\footnotetext{
${ }^{10}$ We conduct sensitivity test using lagged values of global factors. The results are discussed in Section V.B.
} 
The dependent variable pertaining to the centrality measure is discussed and computed in Section III.B. The financial centrality metric captures the importance of an economy in the global financial flows network for both resident and non-resident total and specific types of investment flows. The values refer to percentile ranking and are scaled from 0 to 100 , where higher values pertain to more central economies.

For global factors, we include global GDP growth, global risk aversion, global nominal interest rate, global liquidity, and global commodity price level. We expect financial centrality to respond to changes in these factors as they impact the entire global network of financial flows. Global GDP growth is the year-on-year percent change of real global GDP, sourced from IMF's World Economic Outlook Database. Global risk aversion (VIX) is the annual average value of CBOE VIX accessed through Datastream. Global interest rate refers to the weighted average of long-term interest rate across economies using GDP in constant prices as weights. Data is sourced from Oxford Economics. For global liquidity, we use the global liquidity measure of the Bank of International Settlements. The data pertain to global total bank claims across all currencies and instruments. The inclusion of global interest rate and global liquidity reflects the post-crisis monetary policy stance in advanced economies of low interest rate and high liquidity. The global commodity price index pertains to the All Commodity Price Index, which includes both fuel and non-fuel price indices, with base year set in 2005 (2005 = $100)$. The annual index is the average of the monthly price index, taken from IMF's Commodity Price Database.

For domestic factors, we consider domestic GDP growth, governance, financial depth, domestic real interest rate, and capital account openness. We expect economies with stronger growth, better governance, more developed financial system, and more financially open to have greater importance in the global financial flows network. Domestic GDP growth rate is the year-on-year percent change of real GDP, sourced from IMF's World Economic Outlook Database. The domestic governance indicator is an unweighted index of the average of percentile ranking of control of corruption, government effectiveness, political stability and absence of violence, regulatory quality, rule of law, and voice and accountability, sourced from the World Bank's World Governance Indicators. The domestic financial depth refers to domestic credit provided by the financial sector in percent of nominal GDP. Data are taken from the World Bank's World Development Indicators. The domestic real interest rate pertains to the percent difference between annual long-term government bond yields sourced from the IMF's International Financial Statistics or domestic lending rate taken from the IMF's International Financial Statistics; and domestic annual inflation in percent taken from the IMF's World Economic Outlook Database. Capital account openness is the standardized Chinn-Ito Capital Account Index (Chinn and Ito, 2006) scaled to 100, where higher values refer to less capital account restrictions.

Table 3 presents the summary statistics including the mean, standard deviation, minimum and maximum values of both the dependent and independent variables. Note that 
some samples are dropped as some economies do not have available data on financial depth and domestic real interest rate. The summary statistics also indicate that amongst the regressors, financial depth exhibits the greatest variability.

\section{Results and Analysis}

\section{A. Baseline Results and Extensions}

Table 4 presents the baseline results on the determinants of financial centrality for resident and non-resident capital flows across different types. Several key findings are noted. First, the estimates indicate that both global and domestic factors are significant in explaining financial centrality such that there is no one factor which dominates in importance. This finding contrasts with some of the existing literature on capital flows which point to the dominance of global factors during extreme episodes (Byrne and Fiess, 2016; Calvo et al., 1996; and Forbes and Warnock, 2012). Second, domestic factors appear significant across both resident and non-resident driven financial centrality measures; while global factors appear more relevant for resident based financial centrality as there are few significant global factors in columns (6) to (9) of Table 4. Third, there are contrasting significance of both systemic and idiosyncratic factors on financial centrality across different types of investments and investors. For instance, although higher global risk aversion significantly covaries with weaker financial centrality for resident direct and other investments, it covaries positively with greater financial centrality for resident-based portfolio flows. This can be attributed to flight to safety where most safe assets are transacted or intermediated in financial centres during episodes of financial stress.

In addition, there are several noteworthy results. For global factors, the estimates in Table 4 show that global liquidity increases financial centrality of resident-based total, direct, and other investment flows. For instance, a one percent increase in global liquidity relative to global GDP significantly covaries with higher financial centrality percentile ranking of around 0.35 unit for total resident capital outflows, a 0.52 unit increase for resident direct investment outflows, and a 0.35 unit increase for resident other investment outflows. This suggests that higher global liquidity tends to increase financial centrality of economies on average. In contrast, we find weak evidence on the significance of the global interest rate. Taken together, these results highlight the importance of global liquidity in driving financial centrality, as compared to global interest rate.

For domestic factors, the results indicate the significance of domestic GDP growth, financial depth, and capital account openness. The estimates for these factors are significant across different types of investments and investors. Higher GDP growth leads to greater centrality as the economy becomes a more attractive investment destination and/or more important source of external finance. In other words, an economy with robust growth tends to borrow and invest more abroad, thereby increasing its financial influence. Greater financial 
depth is consistently significant across specifications. Specifically, a one percent increase in domestic financial depth, measured as total credit provided by the financial sector, increases financial centrality by around 0.13 units for both resident and non-resident based gross capital flows. This provides another evidence on the importance of financial depth, development and sophistication in raising the importance of an economy in the global financial flows network, primary due to its importance as a centre for cross-border financial intermediation. In addition, Table 4 results indicate the importance of capital account openness on financial centrality particularly for non-resident based financial transaction flows.

Tables 5 and 6 split the sample into advanced and emerging economies. ${ }^{11}$ The baseline results hold. However, there are notable differences. The domestic real interest has become significantly negative for advanced economies, as shown in Table 5. This means that a higher domestic real interest rate tends to reduce an economy's importance in the global financial flows network due to the higher cost of domestic financial intermediation or higher returns provided in the domestic financial market. These will reduce cross-border financial flows, which diminishes an economy's financial centrality. In addition, greater capital account openness tends to also diminish an emerging economy's financial centrality, as indicated in Table 6. This counterintuitive finding might be due to our financial centrality measure which accounts not only for the number of ties or links but also the importance of counterparties. An emerging economy which has removed restrictions might establish more links with other economies, but those economies might not be those that have high eigenvector centrality score. Hence, we see an overall decline of financial centrality for emerging economies with less capital account restrictions.

In summary, the baseline results show the relevance of both network systemic and idiosyncratic factors on the importance of an economy in the global financial flows network. The findings also highlight the significance of financial depth on financial centrality such that a deeper, more developed, and more sophisticated financial sector tends to play a greater role in cross-border financial intermediation. The results also show the varying significance of global and domestic factors in explaining financial centrality across different types of investments and investors.

We extend the baseline analysis by considering the likelihood of economies becoming financial centres across different types of financial flows networks. In this extension, we strictly define "financial centres" as those economies belonging to the top quartile group of the percentile rank of the eigenvector financial centrality measure for each year. Table 7 presents the marginal effects of a probit regression model where the dependent variable takes the value

\footnotetext{
${ }^{11}$ Advanced economies include Australia, Austria, Belgium, Canada, Cyprus, Czech Republic, Denmark, Estonia, Finland, France, Germany, Greece, Hong Kong, China, Ireland, Italy, Japan, Korea, Latvia, Lithuania, Luxembourg, Malta, Netherlands, New Zealand, Norway, Portugal, Singapore, Slovakia, Slovenia, Spain, Sweden, Switzerland, Chinese Taipei, United Kingdom, and United States. Emerging economies include Argentina, Brazil, Bulgaria, Chile, China, Croatia, Hungary, India, Indonesia, Iran, Malaysia, Mexico, Papua New Guinea, Philippines, Poland, Romania, Russia, Saudi Arabia, South Africa, Thailand, Turkey, United Arab Emirates, Venezuela, and Vietnam.
} 
of 1 if an economy at a given year is a financial centre, and 0 otherwise. The marginal effects are interpreted based on the mean values of the regressors. The results indicate that increasing global growth, global risk aversion, and global commodity price level decrease the likelihood of economies becoming financial centres, while greater financial depth and capital account openness increase the likelihood of becoming financial centres. These findings hold when we define financial centres as those economies belonging to the top decile of our eigenvector financial centrality measure, as shown in Table 8. In summary, extending the analysis to consider relevant factors explaining the likelihood of economies becoming financial centres indicates that global factors tend to reduce the likelihood of economies becoming financial centres, whereas domestic factors tend to increase it.

\section{B. Sensitivity Tests}

We conduct sensitivity tests on our baseline specification. First, we split the sample into pre, crisis, and post-crisis periods. The results validate the importance of both global and domestic factors. More importantly, they show the significance of financial depth and capital account openness. Second, we introduce country and year fixed effects from our baseline specification. The results hold when we drop domestic factors and add country fixed effects (Table 9), as well as when we drop global factors and add year fixed effects (Table 10). These tests imply that our findings hold under varying specifications.

Additional sensitivity tests were conducted. ${ }^{12}$ These tests involve using different centrality measure and changing global and domestic factors. In almost all the tests, the baseline results hold, suggesting the robustness of our findings. However, there are some tests where the results do not hold. For instance, we use an alternative measure of centrality based on weighted degree centrality, as discussed in Section III.B. This measure accounts for the number of direct connections an economy has weighted by the size of capital flows; however, it does not account for the importance of counterparties. Given that our eigenvector centrality is a better measure, the results greatly differ from those of the baseline. Global factors are insignificant. Domestic real interest rate has become more significant but with opposite sign. Financial depth remains significant with the correct sign. Although these results differ from the baseline, the estimates clearly indicate the importance of domestic factors in explaining various measures of financial centrality. We also test the results using lagged global factors. The findings remain the same, but both lagged global growth and lagged global risk aversion are insignificant. This suggests that financial centrality is highly responsive to contemporaneous global factors, and not lagged global factors.

For the rest of our sensitivity tests, the baseline results hold. First, replacing global growth with advanced economies' output gap taken from the IMF's World Economic Outlook Database shows consistent findings. Second, using the global real interest rate, where we

12 Results of these tests are available upon requests to the authors. 
took the difference between the global interest rate and global inflation sourced from IMF's World Economic Outlook Database, the results remain unchanged. Third, instead of using global liquidity as percent of GDP as in the baseline estimation, we test using global liquidity growth. The findings are the same. Global liquidity is significant with the correct sign. This suggests the relevance of global liquidity level and growth in increasing the importance of economies in the global financial flows network. Fourth, replacing global commodity price level with global commodity inflation shows that centrality is responsive to global commodity price level and not to global commodity price inflation.

Next, the findings are the same when we replace domestic growth with domestic real per capita income sourced from the World Bank's World Development Indicators. Sixth, instead of using an aggregate measure of governance, we use the percentile ranking for rule of law taken from World Governance Indicators. The findings are also similar. Seventh, the baseline results indicate the importance of domestic financial depth in increasing an economy's financial centrality. This key finding holds when we use stock market capitalisation of listed companies in percent of GDP sourced from World Bank's World Development Indicators as a measure for financial depth. This implies that the significance of financial depth is robust to alternative measures of domestic financial depth. Lastly, instead of using capital account openness, which is a de jure measure of financial integration, we use external financial assets and liabilities holdings, sourced from Lane and Milesi-Ferretti (2018), as a measure of de facto financial openness. Again, the baseline results hold, suggesting that regardless of de jure or de facto measures, financial openness is significant increases an economy's centrality.

Overall, these tests validate the baseline results on the importance of global and domestic factors in explaining an economy's importance within the global financial flows network.

\section{Concluding Remarks}

This paper considers both global and domestic factors that significantly covary with an economy's financial centrality within the global financial flows network. The focus on both global and domestic factors captures both network systemic and node idiosyncratic timevarying factors that describe an economy's financial centrality within a network. Using a dataset on bilateral capital flows from 10 advanced reporting economies (Mercado, 2018b), we use the eigenvector centrality measure as an indicator of financial centrality for 64 advanced and emerging economies from 2000-16, disaggregated by different types of investments and investor residency. Our financial centrality measure combines the connections an economy weighted by the volume of transactions as well as the importance of its counterparties in the global financial network. This makes our centrality metric vary across time and types of investments. 
The results indicate the importance of both network systemic factors, which are global factors, as well as idiosyncratic factors, which are domestic factors, in explaining cross-country and period variation in financial centrality. However, the findings reveal heterogenous patterns on the relevance of global and domestic factors on financial centrality depending on the residency and types of capital flows. Nonetheless, among factors considered, the estimates highlight the significance of financial depth as a key factor driving financial centrality across different types of financial transaction flows. This suggests the importance of financial regulation and supervision alongside financial deepening and development in safeguarding financial stability of financial centres. 


\section{References}

Alfaro, L.; S. Kalemli-Ozcan and V. Volosovych, (2005), "Why Doesn't Capital Flow from Rich to Poor Countries? An Empirical Investigation," NBER Working Paper, No. 11901, NBER.

Ahmed, S. and A. Zlate (2014), "Capital Flows to Emerging Market Economies: A Brave New World?" Journal of International Money and Finance, 48: 221-248.

Barrat, A.; M. Barthelemy; R. Pastor-Satorras and A. Vespignani, (2004), "The Architecture of Complex Weighted Networks," Proceedings of the National Academy of Sciences, 101(11): 3747-3752.

Battiston S.; Glattfelder J.B.; Garlaschelli D.; Lillo F.; Caldarelli G., (2010), The Structure of Financial Networks, In Estrada E., Fox M., Higham D., Oppo GL., (Eds.) Network Science, Springer, London.

Battiston, S.; D. Delli Gatti; M. Gallegati; B. Greenwald and J. Stiglitz, (2012a), "Default Cascades: When Does Risk Diversification Increase Stability," Journal of Financial Stability, 8(3): 138-149.

Battiston, S.; D. Delli Gatti; M. Gallegati; B. Greenwald and J. Stiglitz, (2012b), "Liaisons Dangereuses: Increasing connectivity, Risk Sharing, and Systemic Risk," Journal of Economic Dynamics and Control, 36(8): 1121-1141.

Bordo, M. and M. Flandreau, (2003), "Core, Periphery, Exchange Rate Regimes, and Globalization," In Bordo, M., A. Taylor, and J. Williamson (Eds.), Globalization in Historical Perspective. Chicago, University of Chicago Press.

Borgatti, S.; A. Mehra; D.J. Brass and G. Labianca, (2009), "Network Analysis in the Social Sciences," Science, 323(5916): 892-895.

Byrne, J. and N. Fiess, (2016), "International Capital Flows to Emerging Markets: National and Global Determinants," Journal of International Money and Finance, 61: 82-100.

Calderón, C. and M. Kubota, (2013), "Sudden Stops: Are Global and Local Investors Alike?" Journal of International Economics, 89 (1): 122-142.

Chinazzi, M.; G. Fagiolo; J. Reyes and S. Schiavo, (2013), "Post-Mortem Examination of International Financial Network," Journal of Economic Dynamics and Control, 37(8): 1692-1713.

Chinn, M. and H. Ito, (2006), "What Matters for Financial Development? Capital Controls, Institutions, and Interactions," Journal of Development Economics, 18(1): 163-192.

Craig, B. and G. von Peter, (2014), "Interbank Tiering and Money Center Banks," Journal of Financial Intermediation, 23(3): 322-347.

Davis, J., (1979), "The Davis/Holland/Leindhardt Studies: An Overview," In P. Holland and S. Lenidhardt (Eds.), Perspectives on Social Network Research. New York: Academic Press.

Demirer, M.; F. Diebold; L. Liu and K. Yilmaz, (2018), "Estimating Global Bank Network Interconnectedness," Journal of Applied Economics, 33(1): 1-15. 
Ding, H.; Y. Jin; Z. Liu and W. Xie, (2019), "The Relationship Between International Trade and Capital Flow: A Network Perspective," Journal of International Money and Finance, 91: $1-11$.

Diebold, F. and K. Yilmaz, (2014), "On the Network Topology of Variance Decompositions: Measuring the Connectedness of Financial Firms," Journal of Econometrics, 182(1): 119-134.

Forbes, K. and F. Warnock, (2012), "Capital Flow Waves, Surges, Stops, Flights and Retrenchment," Journal of International Economics, 88 (2): 235-251.

Fratzscher, M., (2012), "Capital Flows Push versus Pull Factors and the Global Financial Crisis," Journal of International Economics, 88(2): 341-365.

Garlaschelli, D. M., (2007), "Interplay Between Topology and Dynamics in The World Trade Web," The European Physical Journal B, 57: 159-164.

Georg, C., (2013), "The Effect of The Interbank Network Structure on Contagion and Common Shocks," Journal of Banking and Finance, 37(7): 2216-2228.

Giordani, P.; M. Ruta; H. Weisfeld and L. Zhu, (2017), "Capital Flow Deflection," Journal of International Economics, 105: 102-118.

Ghosh, A.; J. Kim; M. Qureshi and J. Zalduendo, (2014), "Surges," Journal of International Economics, 92(2): 266-285.

Hale, G., (2012), "Bank Relationships, Business Cycles, and Financial Crises," Journal of International Economics, 88: 312-325.

Hansen, D.; B. Shneiderman and M. Smith, (2011), "Calculating and Visualizing Network Metrics," In Analyzing Social Media Networks with NodeXL: Insights from a Connected World (2nd ed., pp. 67-98), Burlington: Elsevier Inc.

Hidalgo, C.; F. Heider and G. Runstler, (2015), The Euro Area Money Market Network During the Financial Crisis: A Look at Cross-Border Fragmentation GFI Conference, Bank for International Settlement.

Holland, P. and S. Leinhardt, (1979), "The Advanced Research Symposium on Social Networks," In P. Holland and S. Leinhardt (Eds.), Perspectives on Social Network Research. New York: Academic Press.

lacobucci, D.; D. Popovich; R. McBride and M. Rouziou, (2017), "Social Network Analysis, Which Centrality Index Should I Use?: Theoretical Differences and Empirical Similarities among Top Centralities," Journal of Methods and Measurement in the Social Sciences, 8(2): 72-99.

Kaminsky, G. and C. Reinhart, (2003), "The Centre and the Periphery: The Globalization of Financial Turmoil," NBER Working Paper, 9479, NBER.

Koepke, R., (2018), "What Drives Capital Flows to Emerging Markets? A Survey of Empirical Literature," Journal of Economic Surveys, 33(2): 516-540.

Lane, P. R. and G. M. Milesi-Ferretti, (2018), "The External Wealth of Nations Revisited: International Financial Integration in the Aftermath of the Global Financial Crisis," IMF Economic Review, 66(1): 189-222. 
Leij, M.; D. Veld and C. Hommes, (2016), "The Formation of Core-Periphery Structure in Heterogeneous Financial Networks," DBN Working Paper, No. 528, De Nederlandsche Bank.

Li, S. and H. Yang, (2017), "Interactions of International Portfolio Flows: An Empirical Study Based on Network Analysis," Procedia Computer Science, 122: 826-833.

Li, S.; J. de Haan and B. Scholterns, (2018), "Surges in International Fund Flows," Journal of International Money and Finance, 82: 97-119.

Marsden, P., (2015), "Network Centrality, Measures of," International Encyclopaedia of the Social and Behavioural Sciences, 532-539.

Mercado, R., (2018a), "Not All Surges of Gross Capital Inflows Are Alike," Journal of Economic Studies, 45(2): 326-347.

Mercado, R., (2018b), "Bilateral Capital Flows: Transaction Patterns and Gravity," Trinity Economics Papers, No. 0218, Trinity College Dublin.

Mercado, R., (2018c), "Bilateral Capital Flows: Gravity, Push and Pull," Trinity Economics Papers, No. 0818, Trinity College Dublin.

Mercado, R. and C.Y. Park, (2011), "What Drives Different Types of Capital Flows and Their Volatilities in Developing Asia?" International Economic Journal, 27(4): 497-524.

Minoiu, C. and J. Reyes, (2013), “A Network Analysis of Global Banking: 1978-2010,” Journal of Financial Stability, 9: 168-184.

Newman, M.E.J, (2004), "Analysis of Weighted Networks," Physical Review E, 70(5).

Reinhart, C. and V. Reinhart, (2009), "Capital Flow Bonanzas: An Encompassing View of the Past and Present," NBER International Seminar on Macroeconomics 2008.

Rey, H., (2013), "Dilemma Not Trilemma: The Global Financial Cycle and Monetary Policy Independence," In Federal Reserve Bank of Kansas City Jackson Hole Economic Symposium Proceedings, pp. 285-333, Federal Reserve Bank of Kansas City.

Rey, H., (2016), "International Channels of Transmission of Monetary Policy and the Mundellian Trilemma," IMF Economic Review, 64(1): 6-35.

Steketee, M.; A. Miyako and M. Spiegelman, (2015), "Social Network Analysis," In J. Wright (Ed.), International Encyclopaedia of the Social Behavioural Sciences (2nd ed., Vol. 11, pp. 461-467), Oxford: Elsevier.

Watkins, D.S., (2010), Fundamentals of Matrix Computations ( $2^{\text {nd }}$ ed.), John Wiley \& Sons Inc., New York.

Wellman, B., (1983), “Network Analysis: Some Basic Principles," Sociological Theory, 1: 155200. 
Figures

Figure 1: Schematic Diagram of Reporting Bilateral Capital Flows

a) Bilateral Assets Flows

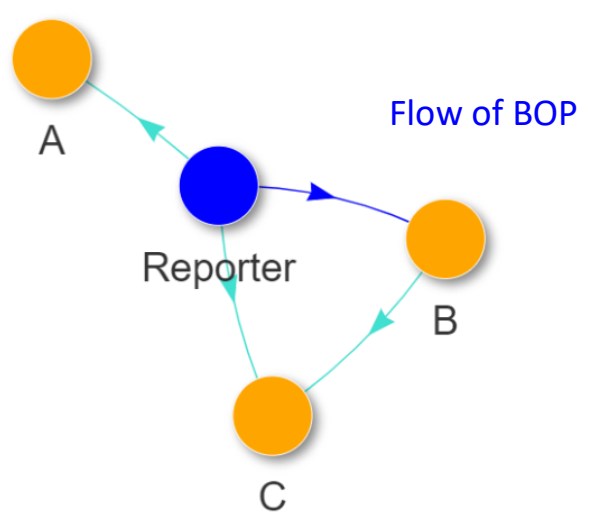

b) Bilateral Liabilities Flows

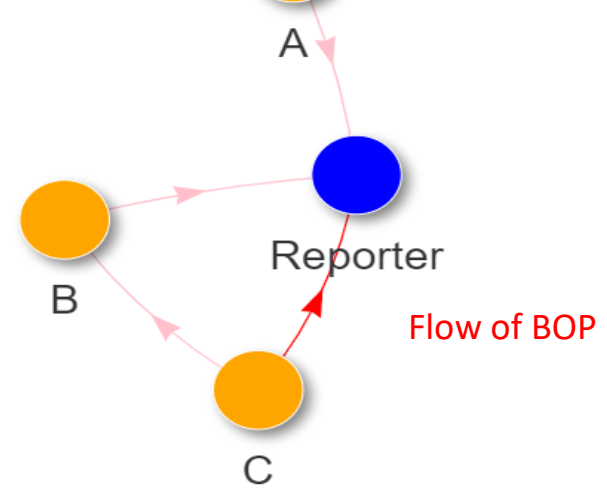


Figure 2: Aggregation of Multiple Reported Asset and Liability Flows

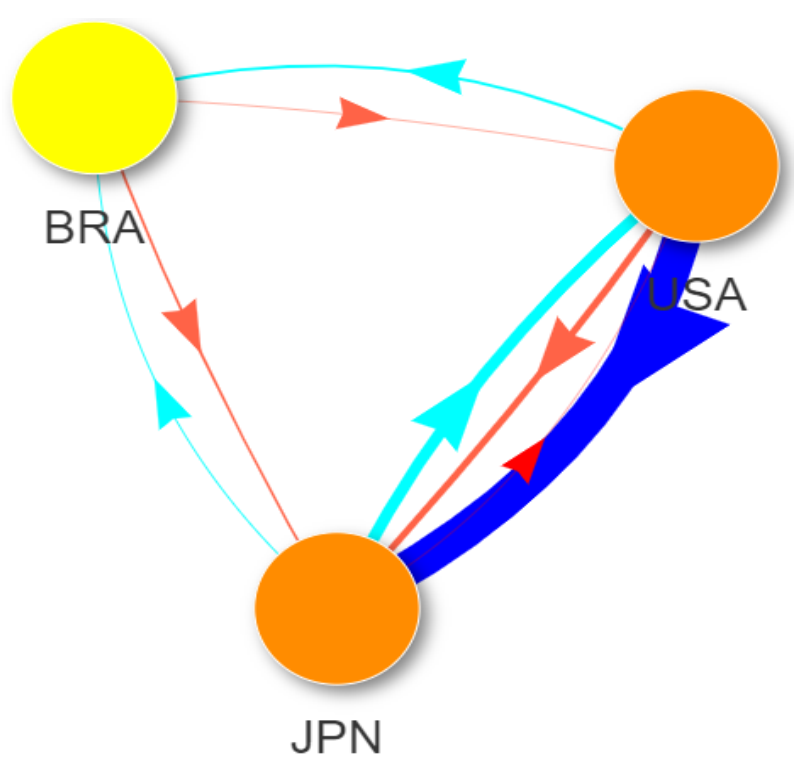


Figure 3: Centrality of Financial Flow Network

a) Financial Asset Network

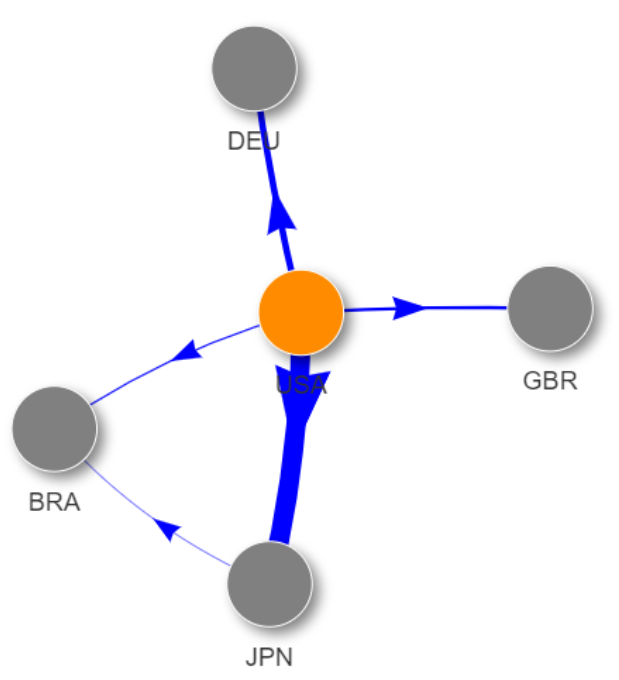

b) Financial Liability Network

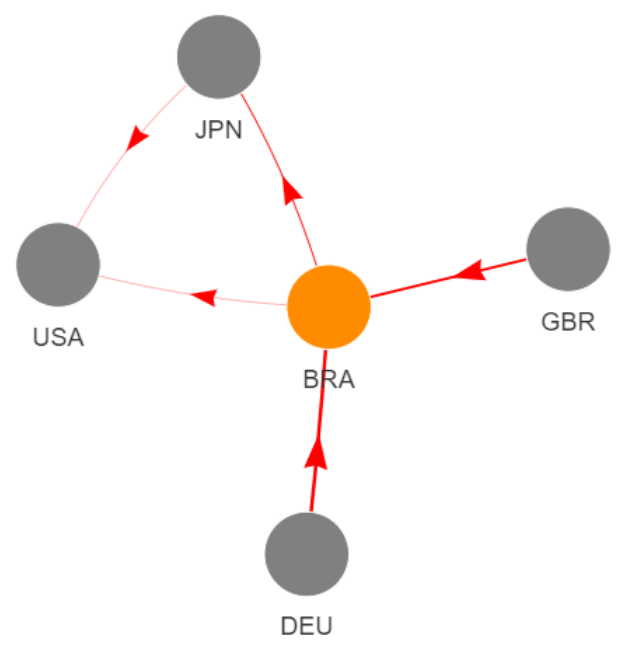


Figure 4: Eigenvector Centrality Index at Network Level

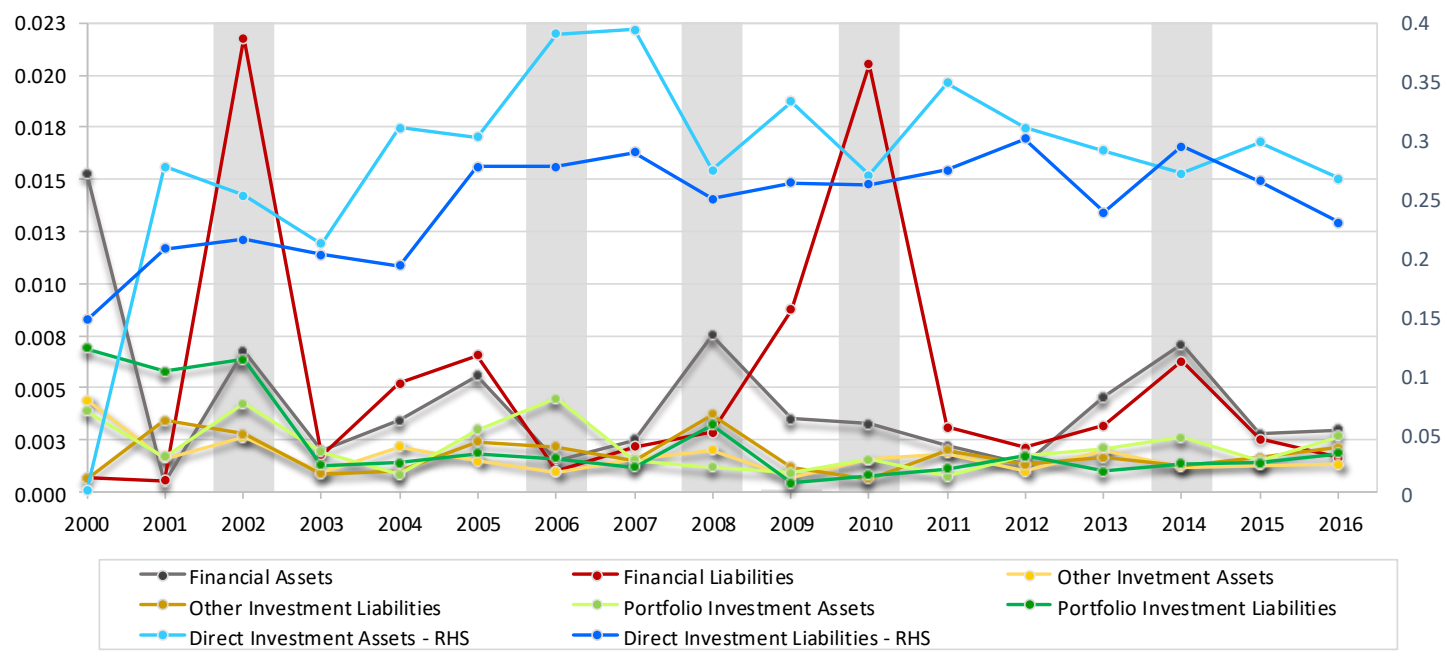




\section{Figure 5: Multiplex Financial Flow Networks}

a) Financial Asset Network Before Crisis

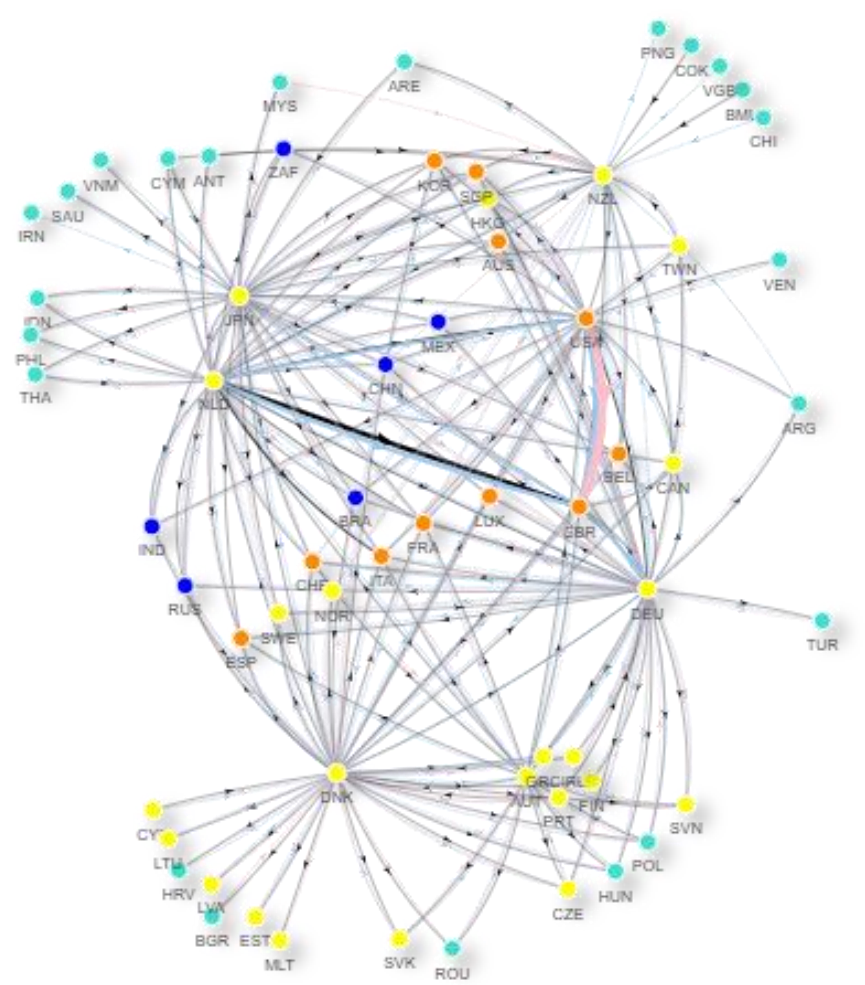

b) Financial Liability Network Before Crisis

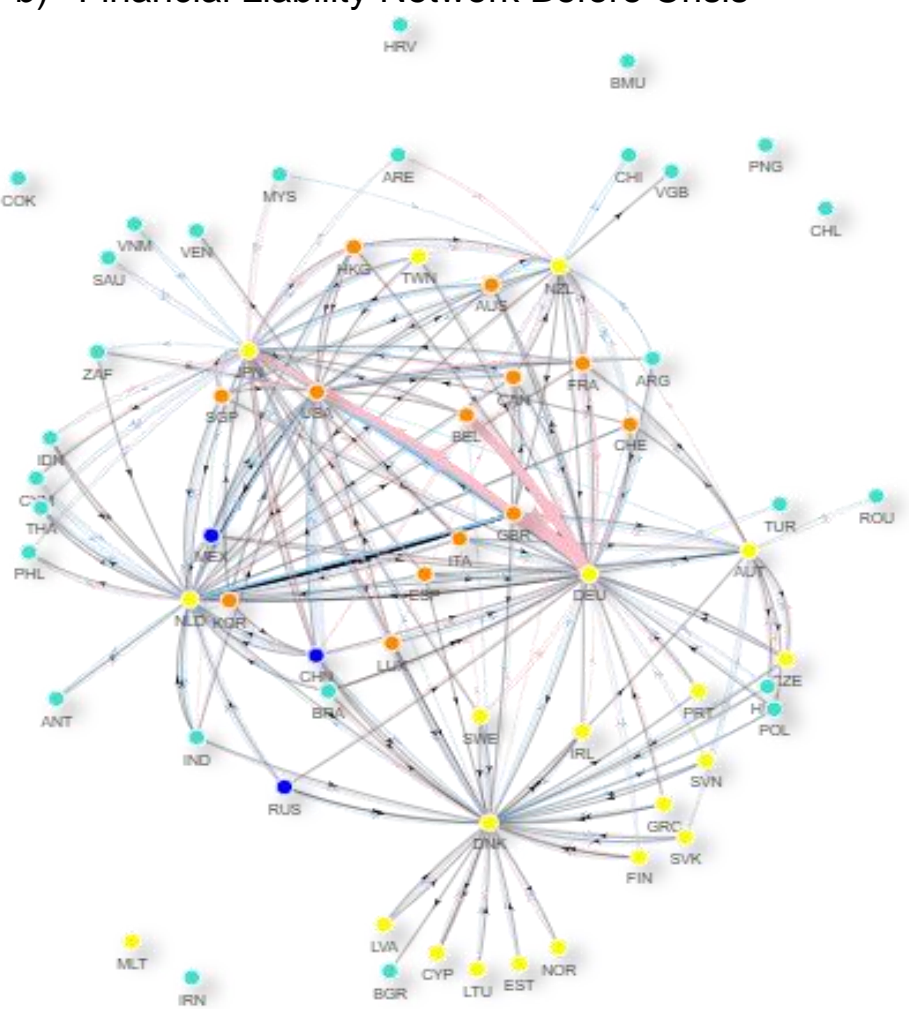




\section{Figure 5: Multiplex Financial Flow Networks}

c) Financial Asset Network During Crisis

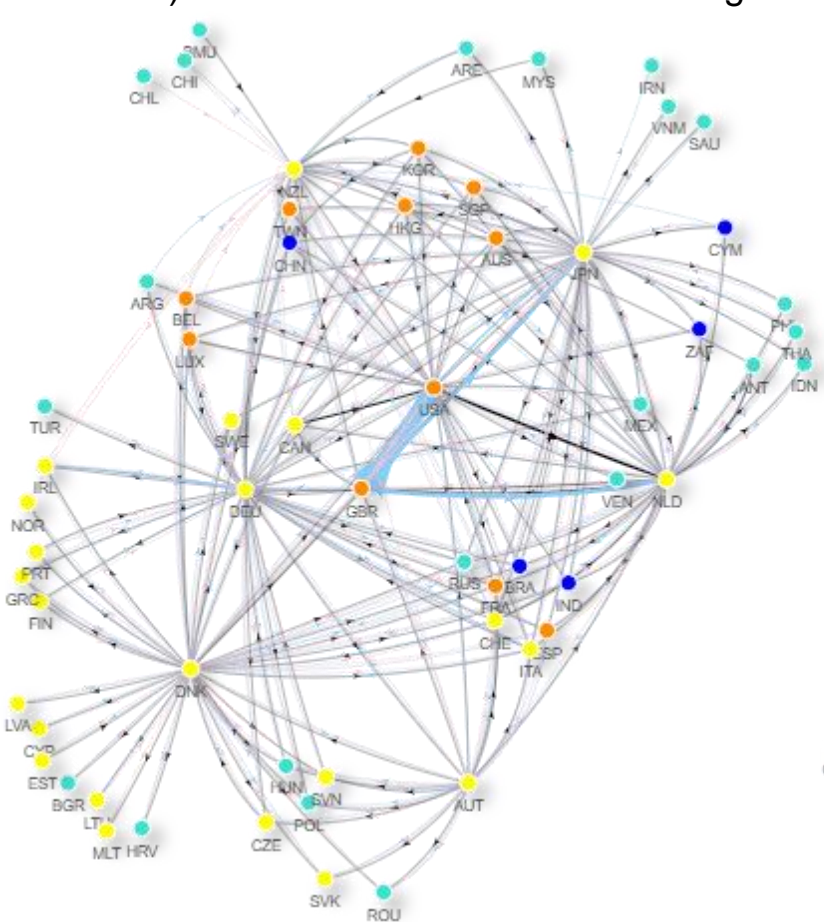

d) Financial Liability Network During Crisis
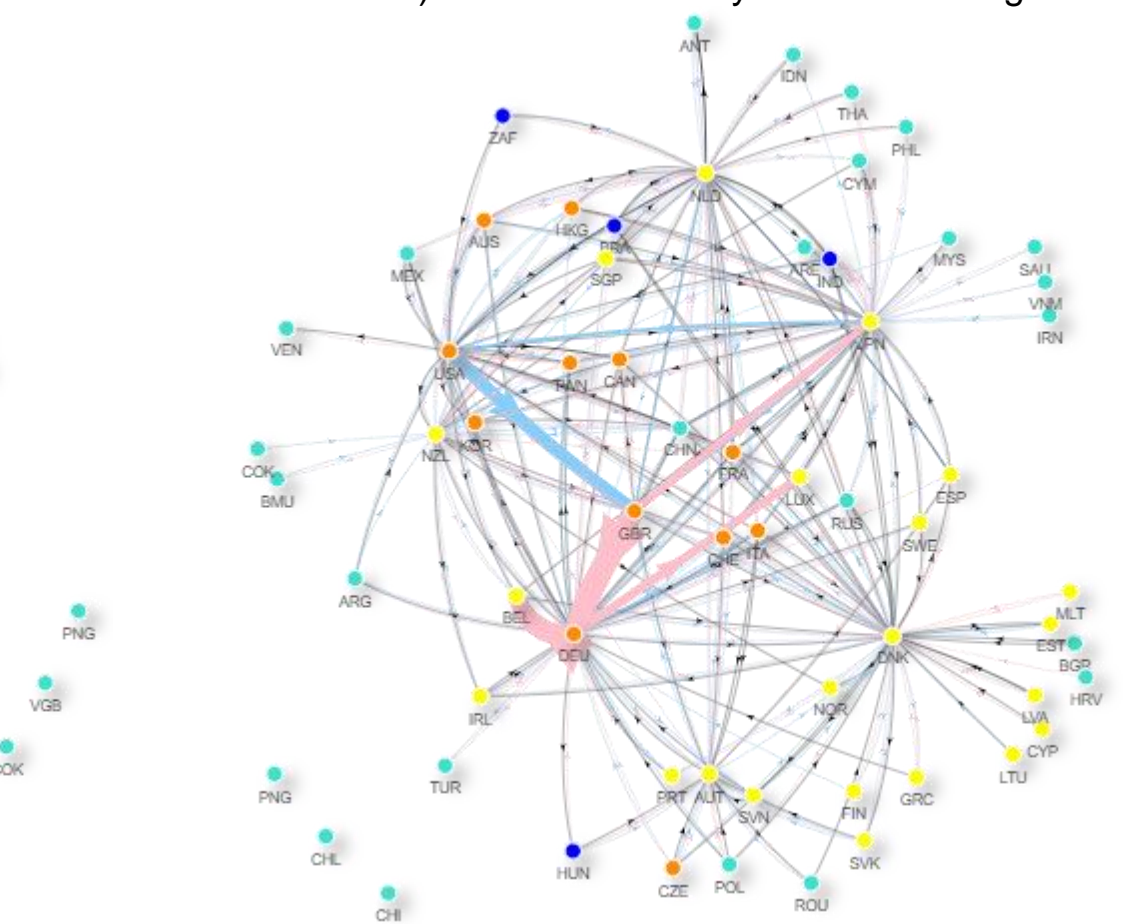


\section{Figure 5: Multiplex Financial Flow Networks}

e) Financial Asset Network After Crisis

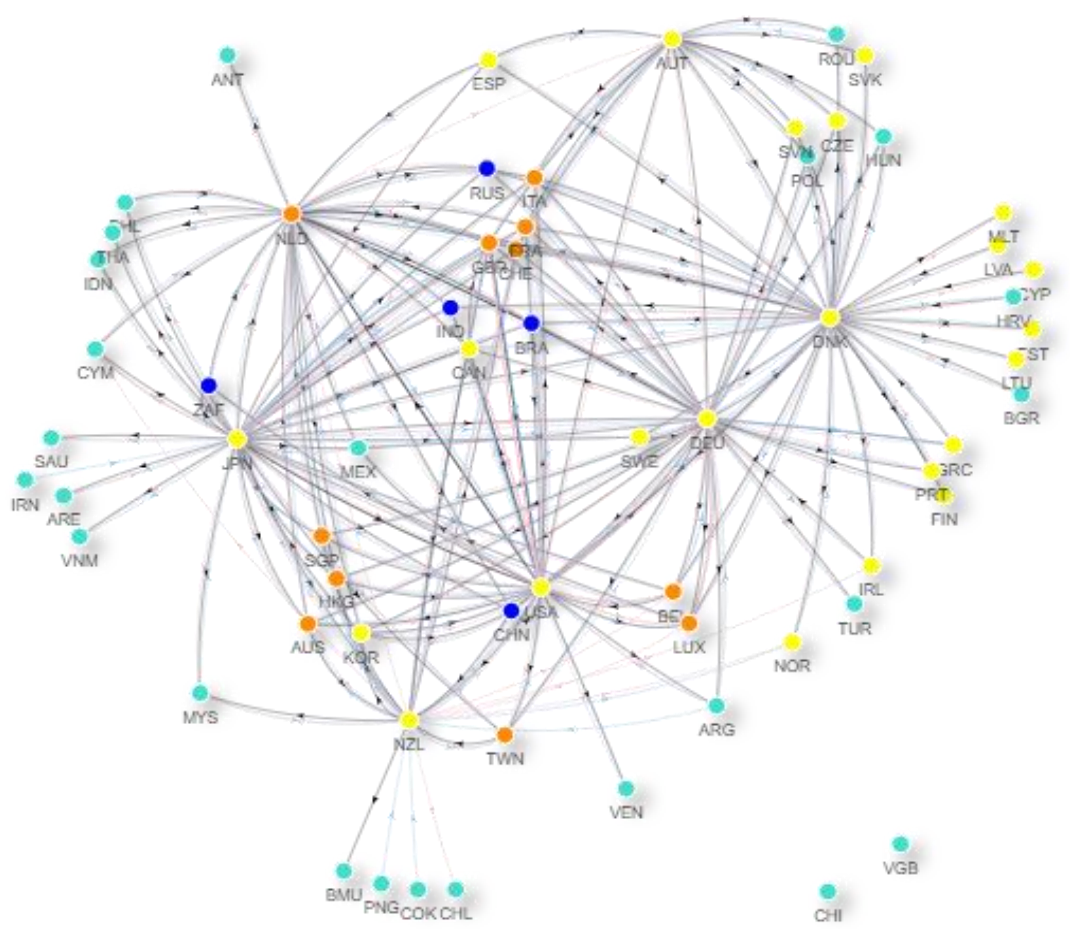

f) Financial Liability Network After Crisis

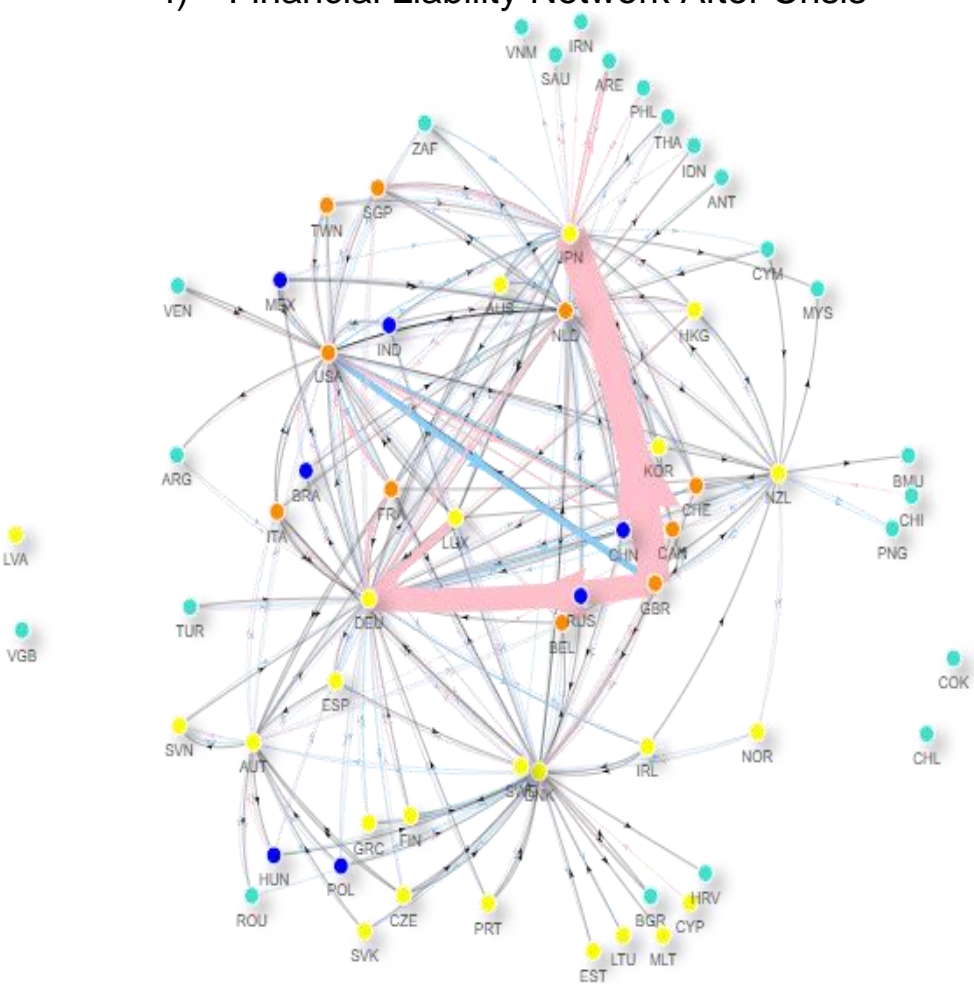




\section{Tables}

Table 1: Bilateral Financial Account Flows Data

\begin{tabular}{|c|c|c|c|c|c|c|c|c|c|c|}
\hline & 承 & 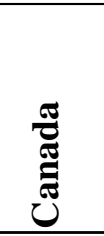 & 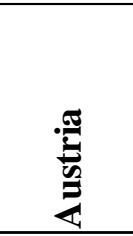 & 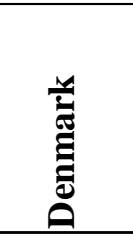 & 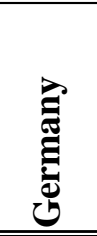 & 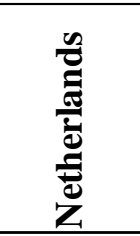 & 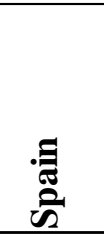 & 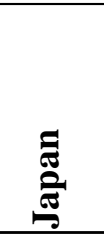 & 递 & 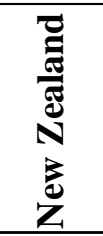 \\
\hline \multicolumn{11}{|l|}{ Foreign Direct Investments } \\
\hline Assets (FDIA) & $\mathrm{TC}$ & $\mathrm{TC}$ & $\mathrm{TC}$ & $\mathrm{TC}$ & $\mathrm{TC}$ & UOHIB & $\mathrm{TC}$ & $\mathrm{TC}$ & $\mathrm{TC}$ & TC \\
\hline Liabilities (FDIL) & $\mathrm{TC}$ & $\mathrm{TC}$ & UOHIB & $\mathrm{TC}$ & $\mathrm{TC}$ & $\mathrm{TC}$ & $\mathrm{TC}$ & $\mathrm{TC}$ & $\mathrm{TC}$ & $\mathrm{TC}$ \\
\hline \multicolumn{11}{|l|}{ Portfolio Investments } \\
\hline Assets (PORTA) & UOHIB & $\mathrm{TC}$ & $\mathrm{TC}$ & UOHIB & $\mathrm{TC}$ & UOHIB & $\mathrm{TC}$ & $\mathrm{TC}$ & $\mathrm{TC}$ & $\mathrm{TC}$ \\
\hline Liabilities (PORTL) & $\mathrm{TC}$ & $\mathrm{TC}$ & (est) & $\mathrm{TC}$ & $\mathrm{TC}$ & (est) & $\mathrm{TC}$ & $\mathrm{TC}$ & $\mathrm{TC}$ & $\mathrm{TC}$ \\
\hline \multicolumn{11}{|l|}{ Financial Derivatives } \\
\hline Assets (DERA) & $x$ & $x$ & $x$ & TC & TC & $\mathrm{TC}$ & $x$ & $\mathrm{TC}$ & $\mathrm{TC}$ & $x$ \\
\hline Liabilities (DERL) & $x$ & $x$ & $x$ & $\mathrm{TC}$ & $\mathrm{TC}$ & $x$ & $x$ & $\mathrm{TC}$ & $\mathrm{TC}$ & $x$ \\
\hline \multicolumn{11}{|l|}{ Other Investment } \\
\hline Assets (OIA) & $\mathrm{TC}$ & $\mathrm{TC}$ & TC & TC & TC & UOHIB & $\mathrm{TC}$ & $\mathrm{TC}$ & $\mathrm{TC}$ & TC \\
\hline Liabilities (OIL) & $\mathrm{TC}$ & $\mathrm{TC}$ & TC & TC & TC & TC & $\mathrm{TC}$ & $\mathrm{TC}$ & $\mathrm{TC}$ & TC \\
\hline Reserve Assets (RESA) & $\mathrm{TC}$ & $\mathrm{TC}$ & $x$ & $\mathrm{TC}$ & $\mathrm{TC}$ & $x$ & $x$ & $x$ & $x$ & $x$ \\
\hline Frequency & Q & Q & Q & M & Q & A & A & Q & A & A \\
\hline Start Year & 2003 & 2000 & 2001 & 2005 & 2000 & 2004 & 2013 & 2000 & 2006 & 2000 \\
\hline End Year & 2016 & 2016 & 2016 & 2016 & 2016 & 2016 & 2016 & 2016 & 2016 & 2016 \\
\hline No. of Counterparty & 21 & 3 & 15 & 36 & 33 & 25 & 7 & 33 & 3 & 30 \\
\hline \multicolumn{11}{|c|}{$\begin{array}{l}\text { Notes: TC = country location of the transacting counterparty. UOHIB }=\text { country location of ultimate } \\
\text { owner, holder, issuer, and beneficiary counterparty. Estimates (est) for Austria and the Netherlands are } \\
\text { based on aggregate portfolio liabilities weighted using derived values from the IMF's Coordinated } \\
\text { Portfolio Investment Survey. Data classification for Korea are assumed to be based on the country } \\
\text { location of the transacting counterparty as no confirmation was given. } A=\text { annual, } Q=\text { quarterly, and M } \\
\text { = monthly. Bilateral financial account flows are sourced from reporting central banks or statistics } \\
\text { agencies. }\end{array}$} \\
\hline
\end{tabular}


Table 2: Bilateral Capital Flows, 2016

(in USD billion)

\begin{tabular}{llllllllll}
\hline Reporter & Partner & FINA & FINL & FDIA & FDIL & PORTA & PORTL & OIA & OIL \\
\hline \hline United States & United Kingdom & 87.10 & 47.56 & 38.88 & 49.07 & -31.18 & 39.85 & 79.40 & -41.36 \\
United States & Germany & -4.36 & 66.38 & 5.92 & 14.05 & -16.56 & 54.58 & 6.28 & -2.25 \\
United States & Japan & 71.81 & 182.95 & 2.27 & 33.91 & 35.11 & 88.26 & 34.43 & 60.77 \\
United States & China & 5.97 & -253.66 & 9.47 & 10.34 & -5.94 & -269.91 & 2.44 & 5.91 \\
Germany & United States & 57.31 & -7.44 & 13.35 & 6.30 & 33.70 & -18.65 & 9.46 & 4.90 \\
Germany & United Kingdom & 58.06 & 574.35 & 8.75 & 6.96 & 0.63 & 435.89 & 29.92 & 131.50 \\
Germany & Austria & -4.74 & -5.59 & 0.77 & -3.10 & -4.22 & 1.64 & -1.66 & -4.13 \\
Germany & Japan & 2.89 & 0.03 & 1.02 & 0.17 & -3.92 & 0.87 & 6.38 & -1.01 \\
Japan & United States & 176.41 & -94.41 & 52.21 & 5.76 & 163.70 & -24.40 & 58.03 & 16.42 \\
Japan & United Kingdom & -133.82 & 852.44 & 47.81 & 5.88 & 2.53 & 964.46 & -12.47 & 53.79 \\
Japan & Germany & -1.56 & -7.43 & 2.33 & 0.35 & -5.68 & -9.73 & 11.77 & 10.93 \\
Japan & China & 12.77 & 104.17 & 8.64 & -0.13 & -0.11 & 100.82 & 4.38 & 3.52 \\
\hline
\end{tabular}

Notes: Bilateral financial account flows data are sourced from reporting central banks or statistics agencies. Japan reports around JPY104,554 billion liabilities from the United Kingdom in 2016. The USD964.46 billion was derived by converting quarterly values in US dollar using average exchange rate from the International Financial Statistics. The reversal of gross capital outflows (FINA) is due to financial derivatives and reserve assets. 
Table 3: Summary Statistics

\begin{tabular}{lrrrrr}
\hline \multicolumn{1}{c}{ Variables } & Obs & \multicolumn{1}{c}{ Mean Std. Dev. } & Min & Max \\
\hline \hline centrality_net flows & 1,088 & 24.7 & 23.7 & 0.0 & 100.0 \\
centrality_FINA & 1,088 & 28.6 & 27.5 & 0.0 & 100.0 \\
centrality_FDIA & 1,088 & 29.5 & 26.2 & 0.0 & 100.0 \\
centrality_PORTA & 1,088 & 25.3 & 25.6 & 0.0 & 100.0 \\
centrality_OIA & 1,088 & 25.4 & 25.8 & 0.0 & 100.0 \\
centrality_FINL & 1,088 & 23.2 & 25.3 & 0.0 & 100.0 \\
centrality_FDIL & 1,088 & 24.6 & 27.5 & 0.0 & 100.0 \\
centrality_PORTL & 1,088 & 21.2 & 25.5 & 0.0 & 100.0 \\
centrality_OIL & 1,088 & 21.3 & 23.9 & 0.0 & 100.0 \\
& & & & & \\
Global GDP Growth & 1,088 & 3.9 & 1.4 & -0.2 & 5.6 \\
VIX & 1,088 & 20.8 & 6.8 & 11.6 & 40.0 \\
Global Interest Rate & 1,088 & 4.4 & 0.9 & 2.7 & 6.0 \\
Global Liquidity & 1,088 & 47.0 & 7.0 & 35.6 & 63.4 \\
Global Commodity Price & 1,088 & 121.9 & 46.5 & 58.2 & 192.6 \\
Domestic GDP Growth & 1,037 & 3.0 & 3.7 & -14.8 & 25.1 \\
Governance & 1,037 & 70.4 & 22.6 & 8.9 & 99.8 \\
Financial Depth & 986 & 108.6 & 63.0 & 0.2 & 345.7 \\
Domestic Real Interest Rate & 986 & 2.5 & 9.3 & -96.4 & 128.2 \\
Capital Account Openness & 1,003 & 73.2 & 32.0 & 0.0 & 10.0 \\
\hline
\end{tabular}

Note: Financial centrality measure pertains to the percentile ranking of the eigenvector central measure. Refer to Section IV for data sources. 
Table 4: Determinants of Centrality - Baseline Results

\begin{tabular}{|c|c|c|c|c|c|c|c|c|c|}
\hline VARIABLES & $\begin{array}{c}(1) \\
\text { NET } \\
\end{array}$ & $\begin{array}{c}(2) \\
\text { FINA } \\
\end{array}$ & $\begin{array}{c}(3) \\
\text { FDIA } \\
\end{array}$ & $\begin{array}{c}(4) \\
\text { PORTA } \\
\end{array}$ & $\begin{array}{c}5) \\
\text { OIA } \\
\end{array}$ & $\begin{array}{c}(6) \\
\text { FINL } \\
\end{array}$ & $\begin{array}{c}(7) \\
\text { FDIL } \\
\end{array}$ & $\begin{array}{c}(8) \\
\text { PORTL } \\
\end{array}$ & $\begin{array}{r}(9) \\
\text { OIL } \\
\end{array}$ \\
\hline Global GDP Growth t $_{\mathrm{t}}$ & $\begin{array}{c}0.356 \\
(0.911)\end{array}$ & $\begin{array}{c}2.777 * * \\
(1.167)\end{array}$ & $\begin{array}{l}-1.192 \\
(1.013)\end{array}$ & $\begin{array}{c}2.597 * * * \\
(0.973)\end{array}$ & $\begin{array}{l}-1.429 \\
(1.013)\end{array}$ & $\begin{array}{c}3.385 * * * \\
(1.071)\end{array}$ & $\begin{array}{l}-0.850 \\
(1.044)\end{array}$ & $\begin{array}{c}0.520 \\
(0.903)\end{array}$ & $\begin{array}{c}0.923 \\
(0.981)\end{array}$ \\
\hline $\mathrm{VIX}_{\mathrm{t}}$ & $\begin{array}{c}-0.163 \\
(0.188)\end{array}$ & $\begin{array}{c}0.543 * * \\
(0.244)\end{array}$ & $\begin{array}{c}-0.365^{*} \\
(0.207)\end{array}$ & $\begin{array}{c}0.565^{* * * *} \\
(0.211)\end{array}$ & $\begin{array}{c}-0.615 * * * \\
(0.210)\end{array}$ & $\begin{array}{c}0.476^{* *} \\
(0.222)\end{array}$ & $\begin{array}{c}-0.241 \\
(0.220)\end{array}$ & $\begin{array}{c}0.010 \\
(0.184)\end{array}$ & $\begin{array}{c}0.047 \\
(0.205)\end{array}$ \\
\hline Global Interest Rate $_{\mathrm{t}}$ & $\begin{array}{c}2.008^{*} \\
(1.107)\end{array}$ & $\begin{array}{l}-1.235 \\
(1.406)\end{array}$ & $\begin{array}{c}1.176 \\
(1.253)\end{array}$ & $\begin{array}{c}0.400 \\
(1.151)\end{array}$ & $\begin{array}{l}3.114 * * \\
(1.257)\end{array}$ & $\begin{array}{c}-0.312 \\
(1.292)\end{array}$ & $\begin{array}{c}0.613 \\
(1.283)\end{array}$ & $\begin{array}{c}0.992 \\
(1.252)\end{array}$ & $\begin{array}{c}0.758 \\
(1.182)\end{array}$ \\
\hline Global Liquidity $_{\mathrm{t}}$ & $\begin{array}{c}0.277 * * \\
(0.108)\end{array}$ & $\begin{array}{c}0.354 * * \\
(0.138)\end{array}$ & $\begin{array}{c}0.517 * * * \\
(0.122)\end{array}$ & $\begin{array}{c}0.011 \\
(0.110)\end{array}$ & $\begin{array}{c}0.354 * * * \\
(0.112)\end{array}$ & $\begin{array}{l}-0.056 \\
(0.123)\end{array}$ & $\begin{array}{c}0.228^{*} \\
(0.131)\end{array}$ & $\begin{array}{c}0.053 \\
(0.108)\end{array}$ & $\begin{array}{c}0.073 \\
(0.105)\end{array}$ \\
\hline Global Commodity Price $_{\mathrm{t}}$ & $\begin{array}{r}-0.019 \\
(0.019) \\
\end{array}$ & $\begin{array}{r}-0.029 \\
(0.024) \\
\end{array}$ & $\begin{array}{r}-0.004 \\
(0.022) \\
\end{array}$ & $\begin{array}{c}0.040 * * \\
(0.021)\end{array}$ & $\begin{array}{c}-0.043^{* *} \\
(0.021)\end{array}$ & $\begin{array}{c}0.019 \\
(0.023) \\
\end{array}$ & $\begin{array}{c}0.011 \\
(0.023) \\
\end{array}$ & $\begin{array}{l}-0.022 \\
(0.021) \\
\end{array}$ & $\begin{array}{l}-0.014 \\
(0.020)\end{array}$ \\
\hline Domestic GDP Growth $_{\mathrm{t}-1}$ & $\begin{array}{c}0.183 \\
(0.174)\end{array}$ & $\begin{array}{c}1.004 * * * \\
(0.253)\end{array}$ & $\begin{array}{c}0.616^{* * * *} \\
(0.224)\end{array}$ & $\begin{array}{c}0.455^{* * *} \\
(0.185)\end{array}$ & $\begin{array}{c}0.180 \\
(0.198)\end{array}$ & $\begin{array}{c}0.704 * * * \\
(0.230)\end{array}$ & $\begin{array}{c}0.455^{* *} \\
(0.230)\end{array}$ & $\begin{array}{c}0.326^{*} \\
(0.184)\end{array}$ & $\begin{array}{c}0.308^{*} \\
(0.173)\end{array}$ \\
\hline Governance $_{\mathrm{t}-1}$ & $\begin{array}{c}0.055 \\
(0.042)\end{array}$ & $\begin{array}{l}-0.025 \\
(0.057)\end{array}$ & $\begin{array}{c}0.054 \\
(0.051)\end{array}$ & $\begin{array}{c}0.071 \\
(0.049)\end{array}$ & $\begin{array}{c}0.029 \\
(0.048)\end{array}$ & $\begin{array}{r}-0.054 \\
(0.052)\end{array}$ & $\begin{array}{c}0.109 * * \\
(0.050)\end{array}$ & $\begin{array}{l}-0.039 \\
(0.046)\end{array}$ & $\begin{array}{c}0.000 \\
(0.046)\end{array}$ \\
\hline Financial Depth $\mathrm{t}_{\mathrm{t}-1}$ & $\begin{array}{c}0.162^{* * * *} \\
(0.015)\end{array}$ & $\begin{array}{c}0.140 * * * \\
(0.017)\end{array}$ & $\begin{array}{c}0.153^{* * * *} \\
(0.016)\end{array}$ & $\begin{array}{c}0.178^{* * *} \\
(0.016)\end{array}$ & $\begin{array}{c}0.173^{* * *} * \\
(0.017)\end{array}$ & $\begin{array}{c}0.133^{* * * *} \\
(0.016)\end{array}$ & $\begin{array}{c}0.162^{* * * *} \\
(0.016)\end{array}$ & $\begin{array}{c}0.204^{* * *} \\
(0.016)\end{array}$ & $\begin{array}{c}0.169^{* * * *} \\
(0.016)\end{array}$ \\
\hline Domestic Real Interest Rate $_{\mathrm{t}-1}$ & $\begin{array}{c}0.086 \\
(0.061)\end{array}$ & $\begin{array}{c}0.193 * * \\
(0.086)\end{array}$ & $\begin{array}{c}0.200 * * \\
(0.083)\end{array}$ & $\begin{array}{l}0.135^{*} \\
(0.074)\end{array}$ & $\begin{array}{l}-0.036 \\
(0.057)\end{array}$ & $\begin{array}{c}0.130 * \\
(0.069)\end{array}$ & $\begin{array}{l}-0.010 \\
(0.077)\end{array}$ & $\begin{array}{c}0.020 \\
(0.051)\end{array}$ & $\begin{array}{l}-0.014 \\
(0.046)\end{array}$ \\
\hline Capital Account Openness ${ }_{t-1}$ & $\begin{array}{c}0.076^{* * * *} \\
(0.027) \\
\end{array}$ & $\begin{array}{c}-0.075^{* *} \\
(0.038) \\
\end{array}$ & $\begin{array}{r}0.015 \\
(0.033) \\
\end{array}$ & $\begin{array}{c}0.053^{*} \\
(0.030) \\
\end{array}$ & $\begin{array}{c}0.080^{* * * *} \\
(0.030)\end{array}$ & $\begin{array}{r}0.000 \\
(0.033) \\
\end{array}$ & $\begin{array}{c}0.092 * * * \\
(0.032)\end{array}$ & $\begin{array}{c}0.147 * * * \\
(0.028)\end{array}$ & $\begin{array}{c}0.063 * * \\
(0.028) \\
\end{array}$ \\
\hline Constant & $\begin{array}{c}-18.910 * * \\
(8.106)\end{array}$ & $\begin{array}{l}-10.906 \\
(10.326)\end{array}$ & $\begin{array}{l}-8.921 \\
(9.284)\end{array}$ & $\begin{array}{c}-31.731 * * * \\
(8.758)\end{array}$ & $\begin{array}{l}-6.768 \\
(9.130)\end{array}$ & $\begin{array}{l}-9.411 \\
(9.691)\end{array}$ & $\begin{array}{l}-13.334 \\
(9.512)\end{array}$ & $\begin{array}{c}-14.610^{*} \\
(8.769)\end{array}$ & $\begin{array}{l}-10.486 \\
(8.795)\end{array}$ \\
\hline Observations & 986 & 986 & 986 & 986 & 986 & 986 & 986 & 986 & 986 \\
\hline R-squared & 0.252 & 0.098 & 0.183 & 0.252 & 0.232 & 0.096 & 0.232 & 0.295 & 0.210 \\
\hline
\end{tabular}

Notes: Dependent variables are financial centrality measure for each type of capital flows and investors.

Refer to Section IV for data sources. Robust standard errors in parentheses. ${ }^{* * *} p<0.01,{ }^{* *} p<0.05$, * $\mathrm{p}<0.1$ 
Table 5: Determinants of Centrality - Advanced Economies

\begin{tabular}{|c|c|c|c|c|c|c|c|c|c|}
\hline VARIABLES & $\begin{array}{c}(1) \\
\text { NET }\end{array}$ & $\begin{array}{c}(2) \\
\text { FINA }\end{array}$ & $\begin{array}{c}(3) \\
\text { FDIA }\end{array}$ & $\begin{array}{c}(4) \\
\text { PORTA }\end{array}$ & $\begin{array}{c}(5) \\
\text { OIA }\end{array}$ & $\begin{array}{c}(6) \\
\text { FINL }\end{array}$ & $\begin{array}{c}(7) \\
\text { FDIL }\end{array}$ & $\begin{array}{c}(8) \\
\text { PORTL }\end{array}$ & $\begin{array}{l}(9) \\
\text { OIL } \\
\end{array}$ \\
\hline Global GDP Growth ${ }_{t}$ & $\begin{array}{c}0.133 \\
(1.360)\end{array}$ & $\begin{array}{l}2.938^{*} \\
(1.692)\end{array}$ & $\begin{array}{l}-2.901 * * \\
(1.427)\end{array}$ & $\begin{array}{l}3.278^{* *} \\
(1.397)\end{array}$ & $\begin{array}{c}-2.843^{* *} \\
(1.446)\end{array}$ & $\begin{array}{l}3.903 * * \\
(1.516)\end{array}$ & $\begin{array}{l}-1.064 \\
(1.483)\end{array}$ & $\begin{array}{c}0.761 \\
(1.390)\end{array}$ & $\begin{array}{c}1.063 \\
(1.465)\end{array}$ \\
\hline VIX $_{t}$ & $\begin{array}{l}-0.318 \\
(0.281)\end{array}$ & $\begin{array}{c}0.496 \\
(0.354)\end{array}$ & $\begin{array}{c}-0.822^{* * *} \\
(0.284)\end{array}$ & $\begin{array}{c}0.643^{* *} \\
(0.300)\end{array}$ & $\begin{array}{c}-1.052^{* * *} \\
(0.301)\end{array}$ & $\begin{array}{c}0.436 \\
(0.312)\end{array}$ & $\begin{array}{l}-0.403 \\
(0.308)\end{array}$ & $\begin{array}{l}-0.009 \\
(0.279)\end{array}$ & $\begin{array}{c}0.023 \\
(0.305)\end{array}$ \\
\hline Global Interest Rate $_{\mathrm{t}}$ & $\begin{array}{c}4.259 * * * \\
(1.614)\end{array}$ & $\begin{array}{c}1.335 \\
(2.013)\end{array}$ & $\begin{array}{l}3.588^{* *} \\
(1.718)\end{array}$ & $\begin{array}{l}3.571 * * \\
(1.594)\end{array}$ & $\begin{array}{c}5.153^{* * * *} \\
(1.806)\end{array}$ & $\begin{array}{c}2.637 \\
(1.844)\end{array}$ & $\begin{array}{c}2.751 \\
(1.857)\end{array}$ & $\begin{array}{c}1.991 \\
(1.881)\end{array}$ & $\begin{array}{c}1.176 \\
(1.727)\end{array}$ \\
\hline Global Liquidity $_{t}$ & $\begin{array}{c}0.205 \\
(0.162)\end{array}$ & $\begin{array}{c}0.161 \\
(0.203)\end{array}$ & $\begin{array}{l}0.340 * \\
(0.173)\end{array}$ & $\begin{array}{c}-0.274 * \\
(0.158)\end{array}$ & $\begin{array}{c}0.204 \\
(0.164)\end{array}$ & $\begin{array}{l}-0.283 \\
(0.174)\end{array}$ & $\begin{array}{c}0.166 \\
(0.198)\end{array}$ & $\begin{array}{l}-0.158 \\
(0.163)\end{array}$ & $\begin{array}{c}0.052 \\
(0.159)\end{array}$ \\
\hline Global Commodity Price $_{t}$ & $\begin{array}{c}-0.051^{*} \\
(0.028)\end{array}$ & $\begin{array}{r}-0.053 \\
(0.033) \\
\end{array}$ & $\begin{array}{r}-0.044 \\
(0.030) \\
\end{array}$ & $\begin{array}{c}0.020 \\
(0.029) \\
\end{array}$ & $\begin{array}{c}-0.074 * * \\
(0.031)\end{array}$ & $\begin{array}{c}0.015 \\
(0.031) \\
\end{array}$ & $\begin{array}{r}-0.018 \\
(0.032) \\
\end{array}$ & $\begin{array}{c}-0.052^{*} \\
(0.031)\end{array}$ & $\begin{array}{r}-0.044 \\
(0.030) \\
\end{array}$ \\
\hline Domestic GDP Growth t-1 $_{\mathrm{t}}$ & $\begin{array}{l}-0.239 \\
(0.288)\end{array}$ & $\begin{array}{c}0.413 \\
(0.401)\end{array}$ & $\begin{array}{l}-0.206 \\
(0.373)\end{array}$ & $\begin{array}{c}0.121 \\
(0.291)\end{array}$ & $\begin{array}{c}-0.744 * * \\
(0.309)\end{array}$ & $\begin{array}{c}0.432 \\
(0.361)\end{array}$ & $\begin{array}{l}-0.200 \\
(0.382)\end{array}$ & $\begin{array}{l}-0.041 \\
(0.317)\end{array}$ & $\begin{array}{l}-0.396 \\
(0.290)\end{array}$ \\
\hline Governance $_{\mathrm{t}-1}$ & $\begin{array}{c}0.476^{* * * *} \\
(0.110)\end{array}$ & $\begin{array}{c}0.090 \\
(0.143)\end{array}$ & $\begin{array}{c}0.177 \\
(0.129)\end{array}$ & $\begin{array}{c}0.344^{* * * *} \\
(0.118)\end{array}$ & $\begin{array}{c}0.365^{* * * *} \\
(0.119)\end{array}$ & $\begin{array}{c}-0.280^{* *} \\
(0.134)\end{array}$ & $\begin{array}{c}0.177 \\
(0.139)\end{array}$ & $\begin{array}{l}-0.038 \\
(0.117)\end{array}$ & $\begin{array}{c}0.351 * * * \\
(0.111)\end{array}$ \\
\hline Financial Depth ${ }_{\mathrm{t}-1}$ & $\begin{array}{c}0.168^{* * * *} \\
(0.018)\end{array}$ & $\begin{array}{c}0.094 * * * \\
(0.019)\end{array}$ & $\begin{array}{c}0.131 * * * \\
(0.020)\end{array}$ & $\begin{array}{c}0.186^{* * * *} \\
(0.020)\end{array}$ & $\begin{array}{c}0.163^{* * *} \\
(0.020)\end{array}$ & $\begin{array}{c}0.109 * * * \\
(0.019)\end{array}$ & $\begin{array}{c}0.148^{* * *} \\
(0.019)\end{array}$ & $\begin{array}{c}0.216^{* * *} \\
(0.019)\end{array}$ & $\begin{array}{c}0.169 * * * \\
(0.020)\end{array}$ \\
\hline Domestic Real Interest Rate t- $1_{1}$ & $\begin{array}{l}-0.664 * \\
(0.383)\end{array}$ & $\begin{array}{c}-1.948^{* * * *} \\
(0.535)\end{array}$ & $\begin{array}{c}-1.653 * * * \\
(0.535)\end{array}$ & $\begin{array}{c}-1.578 * * * \\
(0.426)\end{array}$ & $\begin{array}{c}-1.543 * * * \\
(0.441)\end{array}$ & $\begin{array}{c}-1.961 * * * \\
(0.495)\end{array}$ & $\begin{array}{c}-1.800^{* * * *} \\
(0.509)\end{array}$ & $\begin{array}{c}-1.987 * * * \\
(0.430)\end{array}$ & $\begin{array}{c}-1.212^{* * *} \\
(0.457)\end{array}$ \\
\hline Capital Account Openness ${ }_{t-1}$ & $\begin{array}{c}0.232 * * * \\
(0.047)\end{array}$ & $\begin{array}{c}0.052 \\
(0.081)\end{array}$ & $\begin{array}{c}0.187 * * * \\
(0.061)\end{array}$ & $\begin{array}{c}0.166^{* * * *} \\
(0.059)\end{array}$ & $\begin{array}{c}0.199 * * * * \\
(0.054)\end{array}$ & $\begin{array}{l}0.120^{*} \\
(0.068)\end{array}$ & $\begin{array}{c}0.224 * * * \\
(0.060)\end{array}$ & $\begin{array}{c}0.239 * * * \\
(0.056)\end{array}$ & $\begin{array}{c}0.142 * * * \\
(0.052)\end{array}$ \\
\hline Constant & $\begin{array}{c}-66.333 * * * \\
(14.493)\end{array}$ & $\begin{array}{l}-18.259 \\
(17.399)\end{array}$ & $\begin{array}{c}-7.038 \\
(15.545)\end{array}$ & $\begin{array}{c}-64.070^{* * * *} \\
(14.629)\end{array}$ & $\begin{array}{l}-23.105 \\
(15.548)\end{array}$ & $\begin{array}{c}5.631 \\
(16.204)\end{array}$ & $\begin{array}{l}-21.457 \\
(16.507)\end{array}$ & $\begin{array}{l}-10.468 \\
(15.243)\end{array}$ & $\begin{array}{c}-40.867 * * * \\
(15.097)\end{array}$ \\
\hline Observations & 578 & 578 & 578 & 578 & 578 & 578 & 578 & 578 & 578 \\
\hline R-squared & 0.260 & 0.074 & 0.167 & 0.248 & 0.231 & 0.083 & 0.171 & 0.248 & 0.215 \\
\hline
\end{tabular}

Notes: Dependent variables are financial centrality measure for each type of capital flows and investors. Refer to Section IV for data sources. Advanced economies include Australia, Austria, Belgium, Canada, Cyprus, Czech Republic, Denmark, Estonia, Finland, France, Germany, Greece, Hong Kong, China, Ireland, Italy, Japan, Korea, Latvia, Lithuania, Luxembourg, Malta, Netherlands, New Zealand, Norway, Portugal, Singapore, Slovakia, Slovenia, Spain, Sweden, Switzerland, Chinese Taipei, United Kingdom, and United States. Robust standard errors in parentheses. ${ }^{* * *} p<0.01,{ }^{* *} p<0.05,{ }^{*} p<0.1$ 
Table 6: Determinants of Centrality - Emerging Economies

\begin{tabular}{|c|c|c|c|c|c|c|c|c|c|}
\hline VARIABLES & $\begin{array}{c}(1) \\
\text { NET } \\
\end{array}$ & $\begin{array}{c}(2) \\
\text { FINA }\end{array}$ & $\begin{array}{c}(3) \\
\text { FDIA }\end{array}$ & $\begin{array}{c}(4) \\
\text { PORTA } \\
\end{array}$ & $\begin{array}{c}5) \\
\text { OIA }\end{array}$ & $\begin{array}{c}(6) \\
\text { FINL }\end{array}$ & $\begin{array}{c}(7) \\
\text { FDIL }\end{array}$ & $\begin{array}{c}(8) \\
\text { PORTL } \\
\end{array}$ & $\begin{array}{l}(9) \\
\text { OIL }\end{array}$ \\
\hline Global GDP Growth $_{\mathrm{t}}$ & $\begin{array}{c}0.996 \\
(0.941)\end{array}$ & $\begin{array}{c}2.999 * * \\
(1.393)\end{array}$ & $\begin{array}{c}1.821 \\
(1.245)\end{array}$ & $\begin{array}{c}2.339 * * \\
(1.128)\end{array}$ & $\begin{array}{c}0.988 \\
(1.234)\end{array}$ & $\begin{array}{c}3.473^{* *} \\
(1.401)\end{array}$ & $\begin{array}{c}0.287 \\
(1.248)\end{array}$ & $\begin{array}{c}1.285 \\
(0.880)\end{array}$ & $\begin{array}{c}1.158 \\
(1.131)\end{array}$ \\
\hline VIX $_{t}$ & $\begin{array}{c}0.044 \\
(0.196)\end{array}$ & $\begin{array}{c}0.533 * \\
(0.287)\end{array}$ & $\begin{array}{c}0.246 \\
(0.260)\end{array}$ & $\begin{array}{l}0.452^{*} \\
(0.251)\end{array}$ & $\begin{array}{l}-0.061 \\
(0.246)\end{array}$ & $\begin{array}{c}0.555^{*} \\
(0.291)\end{array}$ & $\begin{array}{c}0.017 \\
(0.267)\end{array}$ & $\begin{array}{c}0.102 \\
(0.184)\end{array}$ & $\begin{array}{c}0.047 \\
(0.232)\end{array}$ \\
\hline Global Interest Rate $_{\mathrm{t}}$ & $\begin{array}{l}-1.578 \\
(1.087)\end{array}$ & $\begin{array}{l}-2.772 \\
(1.817)\end{array}$ & $\begin{array}{l}-1.332 \\
(1.559)\end{array}$ & $\begin{array}{c}-3.674 * * \\
(1.444)\end{array}$ & $\begin{array}{c}0.909 \\
(1.491)\end{array}$ & $\begin{array}{l}-3.009 * \\
(1.621)\end{array}$ & $\begin{array}{l}-2.209 \\
(1.456)\end{array}$ & $\begin{array}{l}-0.102 \\
(1.118)\end{array}$ & $\begin{array}{c}0.569 \\
(1.387)\end{array}$ \\
\hline Global Liquidity $_{t}$ & $\begin{array}{c}0.254^{* * *} \\
(0.110)\end{array}$ & $\begin{array}{c}0.396^{* * *} \\
(0.180)\end{array}$ & $\begin{array}{c}0.517 * * * \\
(0.161)\end{array}$ & $\begin{array}{l}0.232 * \\
(0.134)\end{array}$ & $\begin{array}{c}0.330 * * \\
(0.143)\end{array}$ & $\begin{array}{c}0.065 \\
(0.175)\end{array}$ & $\begin{array}{c}0.079 \\
(0.149)\end{array}$ & $\begin{array}{c}0.123 \\
(0.117)\end{array}$ & $\begin{array}{l}-0.094 \\
(0.125)\end{array}$ \\
\hline Global Commodity Price $_{\mathrm{t}}$ & $\begin{array}{c}0.020 \\
(0.019) \\
\end{array}$ & $\begin{array}{c}0.004 \\
(0.031) \\
\end{array}$ & $\begin{array}{c}0.046 \\
(0.028) \\
\end{array}$ & $\begin{array}{c}0.068 * * * \\
(0.026)\end{array}$ & $\begin{array}{c}-0.009 \\
(0.025) \\
\end{array}$ & $\begin{array}{c}0.029 \\
(0.030) \\
\end{array}$ & $\begin{array}{l}0.050 * \\
(0.028) \\
\end{array}$ & $\begin{array}{c}0.018 \\
(0.020) \\
\end{array}$ & $\begin{array}{c}0.020 \\
(0.022) \\
\end{array}$ \\
\hline Domestic GDP Growth $_{\mathrm{t}-1}$ & $\begin{array}{c}0.422 * * \\
(0.191)\end{array}$ & $\begin{array}{c}0.871^{* * *} \\
(0.308)\end{array}$ & $\begin{array}{c}1.012 * * * \\
(0.273)\end{array}$ & $\begin{array}{c}0.345 \\
(0.218)\end{array}$ & $\begin{array}{c}0.791 * * * \\
(0.237)\end{array}$ & $\begin{array}{c}0.466 \\
(0.291)\end{array}$ & $\begin{array}{c}0.852 * * * \\
(0.252)\end{array}$ & $\begin{array}{c}0.436 * * \\
(0.221)\end{array}$ & $\begin{array}{c}0.834 * * * \\
(0.204)\end{array}$ \\
\hline Governance $_{\mathrm{t}-1}$ & $\begin{array}{c}0.022 \\
(0.048)\end{array}$ & $\begin{array}{c}-0.285^{* * *} \\
(0.068)\end{array}$ & $\begin{array}{l}-0.049 \\
(0.069)\end{array}$ & $\begin{array}{l}-0.012 \\
(0.060)\end{array}$ & $\begin{array}{r}-0.048 \\
(0.060)\end{array}$ & $\begin{array}{c}-0.176 * * \\
(0.070)\end{array}$ & $\begin{array}{l}-0.023 \\
(0.069)\end{array}$ & $\begin{array}{l}-0.056 \\
(0.055)\end{array}$ & $\begin{array}{l}-0.051 \\
(0.058)\end{array}$ \\
\hline Financial Depth $_{\mathrm{t}-1}$ & $\begin{array}{l}0.037 * \\
(0.021)\end{array}$ & $\begin{array}{c}0.178^{* * * *} \\
(0.031)\end{array}$ & $\begin{array}{c}0.075 * * * \\
(0.027)\end{array}$ & $\begin{array}{c}0.066^{* * * *} \\
(0.024)\end{array}$ & $\begin{array}{c}0.081 * * * \\
(0.030)\end{array}$ & $\begin{array}{c}0.127 * * * \\
(0.033)\end{array}$ & $\begin{array}{l}0.054 * \\
(0.030)\end{array}$ & $\begin{array}{c}0.074 * * * \\
(0.023)\end{array}$ & $\begin{array}{c}0.080^{* * * *} \\
(0.025)\end{array}$ \\
\hline Domestic Real Interest Rate $_{t-1}$ & $\begin{array}{c}0.214 * * * \\
(0.083)\end{array}$ & $\begin{array}{c}0.339 * * * \\
(0.101)\end{array}$ & $\begin{array}{c}0.352^{* * * *} \\
(0.094)\end{array}$ & $\begin{array}{c}0.301 * * * \\
(0.097)\end{array}$ & $\begin{array}{c}0.095 \\
(0.071)\end{array}$ & $\begin{array}{c}0.257 * * * \\
(0.078)\end{array}$ & $\begin{array}{c}0.168 * * * \\
(0.062)\end{array}$ & $\begin{array}{c}0.172 * * * \\
(0.064)\end{array}$ & $\begin{array}{c}0.093 \\
(0.061)\end{array}$ \\
\hline Capital Account Openness ${ }_{t-1}$ & $\begin{array}{c}-0.096^{* * * *} \\
(0.026) \\
\end{array}$ & $\begin{array}{c}-0.148 * * * \\
(0.041) \\
\end{array}$ & $\begin{array}{c}-0.154 * * * \\
(0.034) \\
\end{array}$ & $\begin{array}{c}-0.104 * * * \\
(0.032)\end{array}$ & $\begin{array}{r}-0.046 \\
(0.032) \\
\end{array}$ & $\begin{array}{c}-0.108^{* * * *} \\
(0.038)\end{array}$ & $\begin{array}{c}-0.087 * * * \\
(0.034) \\
\end{array}$ & $\begin{array}{r}-0.012 \\
(0.029) \\
\end{array}$ & $\begin{array}{r}-0.026 \\
(0.031) \\
\end{array}$ \\
\hline Constant & $\begin{array}{c}3.043 \\
(8.247)\end{array}$ & $\begin{array}{c}1.411 \\
(13.062)\end{array}$ & $\begin{array}{l}-13.345 \\
(11.781)\end{array}$ & $\begin{array}{c}-5.876 \\
(10.947)\end{array}$ & $\begin{array}{c}-8.195 \\
(10.724)\end{array}$ & $\begin{array}{c}3.952 \\
(12.260)\end{array}$ & $\begin{array}{c}9.747 \\
(11.923)\end{array}$ & $\begin{array}{l}-7.648 \\
(8.417)\end{array}$ & $\begin{array}{c}3.567 \\
(9.661)\end{array}$ \\
\hline Observations & 408 & 408 & 408 & 408 & 408 & 408 & 408 & 408 & 408 \\
\hline R-squared & 0.157 & 0.270 & 0.232 & 0.184 & 0.125 & 0.167 & 0.127 & 0.103 & 0.108 \\
\hline
\end{tabular}

Notes: Dependent variables are financial centrality measure for each type of capital flows and investors.

Refer to Section IV for data sources. Emerging economies include Argentina, Brazil, Bulgaria, Chile, China, Croatia, Hungary, India, Indonesia, Iran, Malaysia, Mexico, Papua New Guinea, Philippines, Poland, Romania, Russia, Saudi Arabia, South Africa, Thailand, Turkey, United Arab Emirates, Venezuela, and Vietnam. Robust standard errors in parentheses. ${ }^{* \star *} p<0.01,{ }^{* *} p<0.05,{ }^{*} p<0.1$ 
Table 7: Determinants of the Likelihood of Centrality - Top Quartile

\begin{tabular}{|c|c|c|c|c|c|c|c|c|c|}
\hline VARIABLES & $\begin{array}{c}(1) \\
\text { NET }\end{array}$ & $\begin{array}{c}(2) \\
\text { FINA }\end{array}$ & $\begin{array}{c}\text { (3) } \\
\text { FDIA }\end{array}$ & $\begin{array}{c}(4) \\
\text { PORTA }\end{array}$ & $\begin{array}{c}(5) \\
\text { OIA }\end{array}$ & $\begin{array}{c}(6) \\
\text { FINL }\end{array}$ & $\begin{array}{c}(7) \\
\text { FDIL }\end{array}$ & $\begin{array}{c}(8) \\
\text { PORTL }\end{array}$ & $\begin{array}{l}9) \\
\text { OIL }\end{array}$ \\
\hline Global GDP Growth $_{t}$ & $\begin{array}{c}-0.0170 * * * \\
(0.0060)\end{array}$ & $\begin{array}{c}0.0007 \\
(0.0114)\end{array}$ & $\begin{array}{c}-0.0379 * * * \\
(0.0092)\end{array}$ & $\begin{array}{l}-0.0058 \\
(0.0065)\end{array}$ & $\begin{array}{c}-0.0257 * * * \\
(0.0074)\end{array}$ & $\begin{array}{c}0.0002 \\
(0.0098)\end{array}$ & $\begin{array}{c}-0.0187 * \\
(0.0102)\end{array}$ & $\begin{array}{c}-0.0108 * * \\
(0.0044)\end{array}$ & $\begin{array}{c}-0.0096^{* *} \\
(0.0044)\end{array}$ \\
\hline VIX $_{\mathrm{t}}$ & $\begin{array}{c}-0.0052 * * * \\
(0.0011)\end{array}$ & $\begin{array}{l}-0.0033 \\
(0.0020)\end{array}$ & $\begin{array}{c}-0.0088^{* * * *} \\
(0.0016)\end{array}$ & $\begin{array}{l}-0.0015 \\
(0.0013)\end{array}$ & $\begin{array}{c}-0.0073 * * * \\
(0.0013)\end{array}$ & $\begin{array}{l}-0.0026 \\
(0.0016)\end{array}$ & $\begin{array}{c}-0.0061^{* * * *} \\
(0.0018)\end{array}$ & $\begin{array}{c}-0.0022^{* *} \\
(0.0009)\end{array}$ & $\begin{array}{c}-0.0023^{* *} \\
(0.0009)\end{array}$ \\
\hline Global Interest Rate $_{t}$ & $\begin{array}{c}0.0076 \\
(0.0059)\end{array}$ & $\begin{array}{c}-0.0224 * \\
(0.0131)\end{array}$ & $\begin{array}{c}0.0041 \\
(0.0110)\end{array}$ & $\begin{array}{l}-0.0068 \\
(0.0067)\end{array}$ & $\begin{array}{c}0.0101 \\
(0.0084)\end{array}$ & $\begin{array}{l}-0.0019 \\
(0.0101)\end{array}$ & $\begin{array}{c}0.0045 \\
(0.0113)\end{array}$ & $\begin{array}{l}-0.0000 \\
(0.0043)\end{array}$ & $\begin{array}{l}-0.0003 \\
(0.0042)\end{array}$ \\
\hline Global Liquidity $_{t}$ & $\begin{array}{c}0.0000 \\
(0.0007)\end{array}$ & $\begin{array}{c}0.0002 \\
(0.0016)\end{array}$ & $\begin{array}{c}0.0019 \\
(0.0012)\end{array}$ & $\begin{array}{c}-0.0017 * * \\
(0.0009)\end{array}$ & $\begin{array}{c}0.0001 \\
(0.0009)\end{array}$ & $\begin{array}{c}-0.0023^{*} \\
(0.0012)\end{array}$ & $\begin{array}{l}-0.0020 \\
(0.0013)\end{array}$ & $\begin{array}{l}-0.0004 \\
(0.0005)\end{array}$ & $\begin{array}{l}-0.0005 \\
(0.0005)\end{array}$ \\
\hline Global Commodity Price $_{t}$ & $\begin{array}{c}-0.0005 * * * \\
(0.0001)\end{array}$ & $\begin{array}{c}-0.0010^{* * * *} \\
(0.0002)\end{array}$ & $\begin{array}{c}-0.0005 * * \\
(0.0002)\end{array}$ & $\begin{array}{c}-0.0005 * * * \\
(0.0002)\end{array}$ & $\begin{array}{c}-0.0005 * * * * \\
(0.0002)\end{array}$ & $\begin{array}{l}-0.0003 \\
(0.0002)\end{array}$ & $\begin{array}{l}-0.0003^{*} \\
(0.0002)\end{array}$ & $\begin{array}{c}-0.0004 * * * * \\
(0.0001)\end{array}$ & $\begin{array}{c}-0.0002^{* *} * \\
(0.0001)\end{array}$ \\
\hline Domestic GDP Growth $_{\mathrm{t}-1}$ & $\begin{array}{c}-0.0039 * * * * \\
(0.0013)\end{array}$ & $\begin{array}{c}0.0041 \\
(0.0028)\end{array}$ & $\begin{array}{c}0.0023 \\
(0.0025)\end{array}$ & $\begin{array}{l}-0.0016 \\
(0.0013)\end{array}$ & $\begin{array}{c}0.0003 \\
(0.0020)\end{array}$ & $\begin{array}{c}0.0018 \\
(0.0020)\end{array}$ & $\begin{array}{l}0.0041^{*} \\
(0.0024)\end{array}$ & $\begin{array}{l}-0.0007 \\
(0.0010)\end{array}$ & $\begin{array}{c}-0.0024 * * * * \\
(0.0009)\end{array}$ \\
\hline Governance $_{t-1}$ & $\begin{array}{c}0.0003 \\
(0.0002)\end{array}$ & $\begin{array}{l}-0.0000 \\
(0.0006)\end{array}$ & $\begin{array}{l}-0.0004 \\
(0.0005)\end{array}$ & $\begin{array}{l}-0.0003 \\
(0.0003)\end{array}$ & $\begin{array}{l}-0.0002 \\
(0.0004)\end{array}$ & $\begin{array}{c}-0.0009 * * \\
(0.0004)\end{array}$ & $\begin{array}{l}-0.0006 \\
(0.0005)\end{array}$ & $\begin{array}{l}-0.0002 \\
(0.0002)\end{array}$ & $\begin{array}{c}0.0002 \\
(0.0002)\end{array}$ \\
\hline Financial Depth $\mathrm{t}_{\mathrm{t}-1}$ & $\begin{array}{c}0.0004 * * * \\
(0.0001)\end{array}$ & $\begin{array}{c}0.0003 * * \\
(0.0002)\end{array}$ & $\begin{array}{c}0.0008^{* * * *} \\
(0.0001)\end{array}$ & $\begin{array}{c}0.0006^{* * * *} \\
(0.0001)\end{array}$ & $\begin{array}{c}0.0008 * * * \\
(0.0001)\end{array}$ & $\begin{array}{c}0.0006 * * * \\
(0.0001)\end{array}$ & $\begin{array}{c}0.0008^{* * * *} \\
(0.0001)\end{array}$ & $\begin{array}{c}0.0004 * * * \\
(0.0001)\end{array}$ & $\begin{array}{c}0.0003 * * * \\
(0.0001)\end{array}$ \\
\hline Domestic Real Interest Rate $_{t-1}$ & $\begin{array}{l}-0.0002 \\
(0.0003)\end{array}$ & $\begin{array}{c}0.0025 * * \\
(0.0011)\end{array}$ & $\begin{array}{c}0.0020^{* *} \\
(0.0009)\end{array}$ & $\begin{array}{c}0.0005 \\
(0.0008)\end{array}$ & $\begin{array}{c}0.0007 \\
(0.0007)\end{array}$ & $\begin{array}{c}0.0007 \\
(0.0006)\end{array}$ & $\begin{array}{c}-0.0011^{* *} \\
(0.0005)\end{array}$ & $\begin{array}{c}-0.0005^{* *} \\
(0.0002)\end{array}$ & $\begin{array}{l}-0.0004 * \\
(0.0002)\end{array}$ \\
\hline Capital Account Openness $\mathrm{t}_{\mathrm{t}-1}$ & $\begin{array}{c}0.0006^{* * * *} \\
(0.0001)\end{array}$ & $\begin{array}{c}0.0000 \\
(0.0004)\end{array}$ & $\begin{array}{c}0.0003 \\
(0.0003)\end{array}$ & $\begin{array}{c}0.0006^{* * * *} \\
(0.0002)\end{array}$ & $\begin{array}{c}0.0006^{* * * *} \\
(0.0002)\end{array}$ & $\begin{array}{c}0.0004 \\
(0.0003)\end{array}$ & $\begin{array}{c}0.0009^{* * * *} \\
(0.0003)\end{array}$ & $\begin{array}{c}0.0006^{* * * *} \\
(0.0002)\end{array}$ & $\begin{array}{l}0.0002^{*} \\
(0.0001)\end{array}$ \\
\hline
\end{tabular}

$\begin{array}{llllllllll}\text { Observations } & 986 & 986 & 986 & 986 & 986 & 986 & 986 & 986 & 986\end{array}$

Notes: Dependent variables are dummy variables where 1 pertains to a country belonging to the top quartile of financial centrality measure for each type of capital flows and investor; and 0 otherwise. The reported values are marginal effects (at the means) of probit regression. Refer to Section IV for data sources. Robust standard errors in parentheses. ${ }^{* * *} p<0.01,{ }^{* *} p<0.05,{ }^{*} p<0.1$ 
Table 8: Determinants of the Likelihood of Centrality - Top Decile

\begin{tabular}{|c|c|c|c|c|c|c|c|c|c|}
\hline VARIABLES & $\begin{array}{c}(1) \\
\text { NET } \\
\end{array}$ & $\begin{array}{c}(2) \\
\text { FINA }\end{array}$ & $\begin{array}{c}\text { (3) } \\
\text { FDIA }\end{array}$ & $\begin{array}{c}(4) \\
\text { PORTA }\end{array}$ & $\begin{array}{l}5) \\
\text { OIA } \\
\end{array}$ & $\begin{array}{c}(6) \\
\text { FINL } \\
\end{array}$ & $\begin{array}{c}(7) \\
\text { FDIL }\end{array}$ & $\begin{array}{c}(8) \\
\text { PORTL } \\
\end{array}$ & $\begin{array}{l}\text { (9) } \\
\text { OIL }\end{array}$ \\
\hline Global GDP Growth $_{t}$ & $\begin{array}{l}-0.0027 \\
(0.0042)\end{array}$ & $\begin{array}{c}0.0072 \\
(0.0079)\end{array}$ & $\begin{array}{c}-0.0117 * * \\
(0.0047)\end{array}$ & $\begin{array}{c}-0.0057^{*} \\
(0.0030)\end{array}$ & $\begin{array}{c}-0.0128 * * * \\
(0.0044)\end{array}$ & $\begin{array}{l}-0.0040 \\
(0.0059)\end{array}$ & $\begin{array}{l}-0.0095^{*} \\
(0.0055)\end{array}$ & $\begin{array}{c}-0.0054^{*} \\
(0.0032)\end{array}$ & $\begin{array}{l}-0.0066^{*} \\
(0.0034)\end{array}$ \\
\hline $\mathrm{VIX}_{\mathrm{t}}$ & $\begin{array}{c}-0.0015^{* *} \\
(0.0007)\end{array}$ & $\begin{array}{l}-0.0012 \\
(0.0013)\end{array}$ & $\begin{array}{c}-0.0021^{* *} \\
(0.0010)\end{array}$ & $\begin{array}{c}-0.0014 * * \\
(0.0006)\end{array}$ & $\begin{array}{c}-0.0027 * * * \\
(0.0009)\end{array}$ & $\begin{array}{l}-0.0017 \\
(0.0011)\end{array}$ & $\begin{array}{c}-0.0028^{* * * *} \\
(0.0010)\end{array}$ & $\begin{array}{c}-0.0013^{* *} \\
(0.0006)\end{array}$ & $\begin{array}{c}-0.0015^{* *} \\
(0.0007)\end{array}$ \\
\hline Global Interest Rate $_{\mathrm{t}}$ & $\begin{array}{c}0.0012 \\
(0.0031)\end{array}$ & $\begin{array}{c}0.0009 \\
(0.0073)\end{array}$ & $\begin{array}{c}0.0031 \\
(0.0041)\end{array}$ & $\begin{array}{c}0.0008 \\
(0.0027)\end{array}$ & $\begin{array}{c}0.0028 \\
(0.0049)\end{array}$ & $\begin{array}{l}-0.0013 \\
(0.0062)\end{array}$ & $\begin{array}{c}0.0075 \\
(0.0046)\end{array}$ & $\begin{array}{c}0.0001 \\
(0.0031)\end{array}$ & $\begin{array}{c}0.0021 \\
(0.0028)\end{array}$ \\
\hline Global Liquidity $_{\mathrm{t}}$ & $\begin{array}{l}-0.0005 \\
(0.0005)\end{array}$ & $\begin{array}{c}-0.0024 * * * \\
(0.0009)\end{array}$ & $\begin{array}{l}-0.0003 \\
(0.0007)\end{array}$ & $\begin{array}{l}-0.0003 \\
(0.0004)\end{array}$ & $\begin{array}{l}-0.0002 \\
(0.0006)\end{array}$ & $\begin{array}{l}-0.0006 \\
(0.0007)\end{array}$ & $\begin{array}{l}-0.0012^{*} \\
(0.0007)\end{array}$ & $\begin{array}{l}-0.0004 \\
(0.0004)\end{array}$ & $\begin{array}{l}-0.0003 \\
(0.0004)\end{array}$ \\
\hline Global Commodity Price ${ }_{t}$ & $\begin{array}{c}-0.0003 * * * \\
(0.0001) \\
\end{array}$ & $\begin{array}{c}-0.0005^{* * * *} \\
(0.0002) \\
\end{array}$ & $\begin{array}{l}-0.0002^{*} \\
(0.0001) \\
\end{array}$ & $\begin{array}{c}-0.0001 * * \\
(0.0001) \\
\end{array}$ & $\begin{array}{c}-0.0002 * * \\
(0.0001) \\
\end{array}$ & $\begin{array}{l}-0.0002 \\
(0.0001) \\
\end{array}$ & $\begin{array}{l}-0.0001 \\
(0.0001) \\
\end{array}$ & $\begin{array}{c}-0.0002 * * \\
(0.0001) \\
\end{array}$ & $\begin{array}{l}-0.0001 \\
(0.0001)\end{array}$ \\
\hline Domestic GDP Growth & $\begin{array}{l}-0.0005 \\
(0.0007)\end{array}$ & $\begin{array}{c}0.0038^{* * * *} \\
(0.0014)\end{array}$ & $\begin{array}{l}-0.0018^{*} \\
(0.0010)\end{array}$ & $\begin{array}{l}-0.0006 \\
(0.0006)\end{array}$ & $\begin{array}{c}0.0002 \\
(0.0013)\end{array}$ & $\begin{array}{l}-0.0011 \\
(0.0012)\end{array}$ & $\begin{array}{l}-0.0019^{*} \\
(0.0010)\end{array}$ & $\begin{array}{c}0.0000 \\
(0.0008)\end{array}$ & $\begin{array}{l}-0.0014^{*} \\
(0.0007)\end{array}$ \\
\hline Governance $_{t-1}$ & $\begin{array}{c}-0.0003^{* *} \\
(0.0001)\end{array}$ & $\begin{array}{l}-0.0003 \\
(0.0003)\end{array}$ & $\begin{array}{l}-0.0002 \\
(0.0002)\end{array}$ & $\begin{array}{c}-0.0003 * * * \\
(0.0001)\end{array}$ & $\begin{array}{l}-0.0003 \\
(0.0002)\end{array}$ & $\begin{array}{c}-0.0006 * * * \\
(0.0002)\end{array}$ & $\begin{array}{c}0.0001 \\
(0.0002)\end{array}$ & $\begin{array}{l}-0.0001 \\
(0.0002)\end{array}$ & $\begin{array}{l}-0.0001 \\
(0.0001)\end{array}$ \\
\hline Financial Depth $_{t-1}$ & $\begin{array}{c}0.0002 * * * \\
(0.0001)\end{array}$ & $\begin{array}{c}0.0003^{* * * *} \\
(0.0001)\end{array}$ & $\begin{array}{c}0.0002 * * \\
(0.0001)\end{array}$ & $\begin{array}{c}0.0002 * * * \\
(0.0001)\end{array}$ & $\begin{array}{c}0.0004 * * * \\
(0.0001)\end{array}$ & $\begin{array}{c}0.0003 * * * \\
(0.0001)\end{array}$ & $\begin{array}{c}0.0002^{* *} \\
(0.0001)\end{array}$ & $\begin{array}{c}0.0003^{* * * *} \\
(0.0001)\end{array}$ & $\begin{array}{c}0.0002^{* * * *} \\
(0.0001)\end{array}$ \\
\hline Domestic Real Interest Rate ${ }_{t-1}$ & $\begin{array}{l}-0.0002 \\
(0.0001)\end{array}$ & $\begin{array}{l}-0.0001 \\
(0.0002)\end{array}$ & $\begin{array}{l}-0.0003 \\
(0.0002)\end{array}$ & $\begin{array}{l}0.0004^{*} \\
(0.0002)\end{array}$ & $\begin{array}{l}-0.0001 \\
(0.0002)\end{array}$ & $\begin{array}{c}0.0003 \\
(0.0003)\end{array}$ & $\begin{array}{l}-0.0004^{*} \\
(0.0002)\end{array}$ & $\begin{array}{c}-0.0003 * \\
(0.0001)\end{array}$ & $\begin{array}{l}-0.0002 \\
(0.0001)\end{array}$ \\
\hline Capital Account Openness ${ }_{t-1}$ & $\begin{array}{c}0.0003 * * * \\
(0.0001) \\
\end{array}$ & $\begin{array}{c}0.0001 \\
(0.0002)\end{array}$ & $\begin{array}{c}0.0003^{* * * *} \\
(0.0001) \\
\end{array}$ & $\begin{array}{c}0.0003 * * * \\
(0.0001)\end{array}$ & $\begin{array}{l}0.0002^{* * *} \\
(0.0001)\end{array}$ & $\begin{array}{l}0.0002^{*} \\
(0.0001)\end{array}$ & $\begin{array}{c}0.0004^{* * * *} \\
(0.0001)\end{array}$ & $\begin{array}{c}0.0003^{* * * *} \\
(0.0001) \\
\end{array}$ & $\begin{array}{c}0.0001 \\
(0.0001)\end{array}$ \\
\hline
\end{tabular}

$\begin{array}{llllllllll}\text { Observations } & 986 & 986 & 986 & 986 & 986 & 986 & 986 & 986 & 986\end{array}$

Notes: Dependent variables are dummy variables where 1 pertains to a country belonging to the top decile of financial centrality measure for each type of capital flows and investors; and 0 otherwise. The reported values are marginal effects (at the means) of probit regression. Refer to Section IV for data sources. Robust standard errors in parentheses. ${ }^{* * *} p<0.01,{ }^{* *} p<0.05,{ }^{*} p<0.1$ 
Table 9: Determinants of Centrality - Global Factors

\begin{tabular}{|c|c|c|c|c|c|c|c|c|c|}
\hline VARIABLES & $\begin{array}{c}(1) \\
\text { NET } \\
\end{array}$ & $\begin{array}{c}(2) \\
\text { FINA }\end{array}$ & $\begin{array}{c}(3) \\
\text { FDIA } \\
\end{array}$ & $\begin{array}{c}(4) \\
\text { PORTA } \\
\end{array}$ & $\begin{array}{l}(5) \\
\text { OIA } \\
\end{array}$ & $\begin{array}{c}(6) \\
\text { FINL } \\
\end{array}$ & $\begin{array}{c}(7) \\
\text { FDIL } \\
\end{array}$ & $\begin{array}{c}(8) \\
\text { PORTL } \\
\end{array}$ & $\begin{array}{l}(9) \\
\text { OIL } \\
\end{array}$ \\
\hline Global GDP Growth $_{\mathrm{t}}$ & $\begin{array}{c}0.414 \\
(0.532)\end{array}$ & $\begin{array}{c}1.810^{* * * *} \\
(0.568)\end{array}$ & $\begin{array}{c}-1.411^{* *} \\
(0.620)\end{array}$ & $\begin{array}{c}2.255^{* * * *} \\
(0.554)\end{array}$ & $\begin{array}{c}-1.225^{* *} \\
(0.622)\end{array}$ & $\begin{array}{c}2.538 * * * \\
(0.733)\end{array}$ & $\begin{array}{l}-0.928 \\
(0.673)\end{array}$ & $\begin{array}{c}0.427 \\
(0.604)\end{array}$ & $\begin{array}{c}0.671 \\
(0.674)\end{array}$ \\
\hline $\mathrm{VIX}_{\mathrm{t}}$ & $\begin{array}{l}-0.114 \\
(0.108)\end{array}$ & $\begin{array}{c}0.309 * * * \\
(0.111)\end{array}$ & $\begin{array}{c}-0.410 * * * \\
(0.123)\end{array}$ & $\begin{array}{c}0.486^{* * *} \\
(0.115)\end{array}$ & $\begin{array}{c}-0.515 * * * \\
(0.124)\end{array}$ & $\begin{array}{c}0.315^{* *} \\
(0.142)\end{array}$ & $\begin{array}{l}-0.222 * \\
(0.133)\end{array}$ & $\begin{array}{c}0.023 \\
(0.120)\end{array}$ & $\begin{array}{c}0.047 \\
(0.138)\end{array}$ \\
\hline Global Interest Rate $_{\mathrm{t}}$ & $\begin{array}{c}0.151 \\
(0.598)\end{array}$ & $\begin{array}{c}-1.442 * * \\
(0.659)\end{array}$ & $\begin{array}{c}0.250 \\
(0.686)\end{array}$ & $\begin{array}{c}-1.242 * \\
(0.725)\end{array}$ & $\begin{array}{c}0.965 \\
(0.779)\end{array}$ & $\begin{array}{l}-1.140 \\
(0.729)\end{array}$ & $\begin{array}{l}-1.175 \\
(0.762)\end{array}$ & $\begin{array}{l}-1.395^{*} \\
(0.809)\end{array}$ & $\begin{array}{l}-1.160 \\
(0.796)\end{array}$ \\
\hline Global Liquidity $y_{t}$ & $\begin{array}{c}0.257 * * * \\
(0.060)\end{array}$ & $\begin{array}{c}0.329 * * * \\
(0.065)\end{array}$ & $\begin{array}{c}0.463 * * * \\
(0.067)\end{array}$ & $\begin{array}{c}0.001 \\
(0.066)\end{array}$ & $\begin{array}{c}0.332 * * * \\
(0.073)\end{array}$ & $\begin{array}{l}-0.033 \\
(0.068)\end{array}$ & $\begin{array}{c}0.239 * * * \\
(0.079)\end{array}$ & $\begin{array}{c}0.059 \\
(0.076)\end{array}$ & $\begin{array}{c}0.082 \\
(0.077)\end{array}$ \\
\hline Global Commodity Price $_{t}$ & $\begin{array}{c}0.003 \\
(0.010) \\
\end{array}$ & $\begin{array}{l}-0.017^{*} \\
(0.011) \\
\end{array}$ & $\begin{array}{c}0.011 \\
(0.011) \\
\end{array}$ & $\begin{array}{c}0.057 * * * \\
(0.013) \\
\end{array}$ & $\begin{array}{r}-0.013 \\
(0.014) \\
\end{array}$ & $\begin{array}{c}0.029 * * \\
(0.012) \\
\end{array}$ & $\begin{array}{c}0.031 * * \\
(0.013) \\
\end{array}$ & $\begin{array}{c}0.007 \\
(0.014) \\
\end{array}$ & $\begin{array}{c}0.008 \\
(0.014) \\
\end{array}$ \\
\hline $\begin{array}{l}\text { Observations } \\
\text { R-squared }\end{array}$ & $\begin{array}{l}1,088 \\
0.734\end{array}$ & $\begin{array}{l}1,088 \\
0.776\end{array}$ & $\begin{array}{l}1,088 \\
0.723\end{array}$ & $\begin{array}{l}1,088 \\
0.688\end{array}$ & $\begin{array}{l}1,088 \\
0.647\end{array}$ & $\begin{array}{l}1,088 \\
0.660\end{array}$ & $\begin{array}{l}1,088 \\
0.693\end{array}$ & $\begin{array}{l}1,088 \\
0.630\end{array}$ & $\begin{array}{l}1,088 \\
0.557\end{array}$ \\
\hline
\end{tabular}

Notes: Dependent variables are financial centrality measure for each type of capital

flows and investors. Regression specification includes country dummy variables. Refer

to Section IV for data sources. Robust standard errors in parentheses. $\star * \star p<0.01$,

** $\mathrm{p}<0.05, * \mathrm{p}<0.1$ 
Table 10: Determinants of Centrality - Domestic Factors

\begin{tabular}{|c|c|c|c|c|c|c|c|c|c|}
\hline VARIABLES & $\begin{array}{c}(1) \\
\text { NET }\end{array}$ & $\begin{array}{c}(2) \\
\text { FINA }\end{array}$ & $\begin{array}{c}\text { (3) } \\
\text { FDIA } \\
\end{array}$ & $\begin{array}{c}(4) \\
\text { PORTA } \\
\end{array}$ & $\begin{array}{c}(5) \\
\text { OIA } \\
\end{array}$ & $\begin{array}{c}(6) \\
\text { FINL } \\
\end{array}$ & $\begin{array}{c}(7) \\
\text { FDIL }\end{array}$ & $\begin{array}{c}(8) \\
\text { PORTL } \\
\end{array}$ & $\begin{array}{l}(9) \\
\text { OIL } \\
\end{array}$ \\
\hline Domestic GDP Growth $\mathrm{t}_{\mathrm{t}-1}$ & $\begin{array}{l}0.353^{*} \\
(0.193)\end{array}$ & $\begin{array}{c}1.047 * * * \\
(0.290)\end{array}$ & $\begin{array}{c}0.637 * * \\
(0.248)\end{array}$ & $\begin{array}{c}0.534 * * * * \\
(0.206)\end{array}$ & $\begin{array}{c}0.349 \\
(0.220)\end{array}$ & $\begin{array}{c}0.687 * * * \\
(0.262)\end{array}$ & $\begin{array}{c}0.551 * * \\
(0.262)\end{array}$ & $\begin{array}{c}0.131 \\
(0.202)\end{array}$ & $\begin{array}{l}0.332 * \\
(0.178)\end{array}$ \\
\hline Governance $_{t-1}$ & $\begin{array}{c}0.054 \\
(0.042)\end{array}$ & $\begin{array}{l}-0.027 \\
(0.057)\end{array}$ & $\begin{array}{c}0.058 \\
(0.051)\end{array}$ & $\begin{array}{c}0.069 \\
(0.049)\end{array}$ & $\begin{array}{c}0.022 \\
(0.048)\end{array}$ & $\begin{array}{l}-0.053 \\
(0.052)\end{array}$ & $\begin{array}{c}0.108 * * \\
(0.051)\end{array}$ & $\begin{array}{l}-0.037 \\
(0.046)\end{array}$ & $\begin{array}{l}-0.007 \\
(0.046)\end{array}$ \\
\hline Financial Depth $_{t-1}$ & $\begin{array}{c}0.163^{* * * *} \\
(0.015)\end{array}$ & $\begin{array}{c}0.141 * * * \\
(0.017)\end{array}$ & $\begin{array}{c}0.152 * * * \\
(0.016)\end{array}$ & $\begin{array}{c}0.180^{* * * *} \\
(0.016)\end{array}$ & $\begin{array}{c}0.176^{* * * *} \\
(0.017)\end{array}$ & $\begin{array}{c}0.133^{* * * *} \\
(0.016)\end{array}$ & $\begin{array}{c}0.164 * * * \\
(0.016)\end{array}$ & $\begin{array}{c}0.203^{* * * *} \\
(0.016)\end{array}$ & $\begin{array}{c}0.170^{* * * *} \\
(0.016)\end{array}$ \\
\hline Domestic Real Interest Rate $_{t-1}$ & $\begin{array}{c}0.082 \\
(0.062)\end{array}$ & $\begin{array}{c}0.193 * * \\
(0.088)\end{array}$ & $\begin{array}{c}0.201 * * \\
(0.083)\end{array}$ & $\begin{array}{l}0.139^{*} \\
(0.074)\end{array}$ & $\begin{array}{l}-0.056 \\
(0.056)\end{array}$ & $\begin{array}{l}0.131^{*} \\
(0.069)\end{array}$ & $\begin{array}{l}-0.018 \\
(0.078)\end{array}$ & $\begin{array}{c}0.027 \\
(0.049)\end{array}$ & $\begin{array}{l}-0.022 \\
(0.048)\end{array}$ \\
\hline Capital Account Openness $s_{t-1}$ & $\begin{array}{c}0.080^{* * * *} \\
(0.027) \\
\end{array}$ & $\begin{array}{l}-0.074 * \\
(0.038) \\
\end{array}$ & $\begin{array}{r}0.013 \\
(0.032) \\
\end{array}$ & $\begin{array}{l}0.055^{*} \\
(0.030) \\
\end{array}$ & $\begin{array}{c}0.088^{* * * *} \\
(0.030)\end{array}$ & $\begin{array}{l}-0.001 \\
(0.034) \\
\end{array}$ & $\begin{array}{c}0.094 * * * * \\
(0.033)\end{array}$ & $\begin{array}{c}0.140 * * * \\
(0.028) \\
\end{array}$ & $\begin{array}{c}0.068^{* *} \\
(0.028) \\
\end{array}$ \\
\hline $\begin{array}{l}\text { Observations } \\
\text { R-squared }\end{array}$ & $\begin{array}{c}986 \\
0.256\end{array}$ & $\begin{array}{c}986 \\
0.102\end{array}$ & $\begin{array}{c}986 \\
0.196\end{array}$ & $\begin{array}{c}986 \\
0.273\end{array}$ & $\begin{array}{c}986 \\
0.258\end{array}$ & $\begin{array}{c}986 \\
0.106\end{array}$ & $\begin{array}{c}986 \\
0.239\end{array}$ & $\begin{array}{c}986 \\
0.305\end{array}$ & $\begin{array}{c}986 \\
0.223\end{array}$ \\
\hline
\end{tabular}

Notes: Dependent variables are financial centrality measure for each type of capital flows and investors. Regression specification includes year dummy variables. Refer to Section IV for data sources. Robust standard errors in parentheses. ${ }^{* * *} p<0.01,{ }^{* *} p<0.05,{ }^{*} p<0.1$ 